\title{
EVALUATION OF AGENTS THAT CAN MODIFY THE RADIATION RESPONSE
}

Borbála Daróczi

Ph.D. Thesis

Ph.D. advisor:

Katalin Hideghéty, M.D., Ph.D.

Department of Oncotherapy

University of Szeged

Szeged

2013 


\section{LIST OF PUBLICATIONS}

\section{List of original articles related to the thesis:}

I. Daroczi B, Kari G, McAleer MF, Wolf JC, Rodeck U, Dicker AP: In vivo radioprotection by the fullerene nanoparticle DF-1 as assessed in a zebrafish model.

CLINICAL CANCER RESEARCH 12:(23) pp. 7086-7091. (2006)

IF: 6.177

II. Daroczi B, Kari G, Ren Q, Dicker AP, Rodeck U: Nuclear factor kappaB inhibitors alleviate and the proteasome inhibitor PS-341 exacerbates radiation toxicity in zebrafish embryos.

MOLECULAR CANCER THERAPEUTICS 8:(9) pp. 2625-2634. (2009)

IF: 4.953

III. Daróczi Borbála, Szántó Erika, Tóth Judit, Barzó Pál, Bognár László, Bakó Gyula, Mózes Petra, Szántó János, Hideghéty Katalin: Postoperative management of primary glioblastoma multiforme in patients over 60 years of age.

IDEGGYÓGYÁSZATI SZEMLE/CLINICAL NEUROSCIENCE in press (2013) IF: 0.488

\section{Other papers:}

I. Davidson WR, Kari C, Ren Q, Daroczi B, Dicker AP, Rodeck U: Differential regulation of p53 function by the N-terminal DeltaNp53 and Delta113p53 isoforms in zebrafish embryos.

BMC DEVELOPMENTAL BIOLOGY 10: p. 102. (2010)

IF: 2.781

II. Wachsberger PR, Lawrence YR, Liu Y, Daroczi B, Xu X, Dicker AP: Epidermal growth factor receptor expression modulates antitumor efficacy of vandetanib or cediranib combined with radiotherapy in human glioblastoma xenografts. INTERNATIONAL JOURNAL OF RADIATION ONCOLOGY BIOLOGY PHYSICS 82:(1) pp. 483-491. (2012)

IF: 4.105

\section{Abstracts directly related to the thesis:}

I. $\quad$ B. Daroczi, M.F. McAleer, G. Kari, U. Rodeck, A.P. Dicker. In vivo evaluation of radioprotection by the fullerene CD60-DF1 using a zebrafish model. AACR-EORTCNCI Meeting, Philadelphia, PA, 2005 
II. B. Daroczi, M.F. McAleer, G. Kari, U. Rodeck, A.P. Dicker. The fullerene DF-1 demonstrates general and organ specific radioprotective effects in a zebrafish model. $97^{\text {th }}$ Annual Meeting, American Association for Cancer Research, Washington DC, 2006

III. B. Daroczi, G. Kari, U. Rodeck, A.P. Dicker. Evaluation of radioprotection by superoxide dismutase mimetics and nanoparticle fullerenes using a zebrafish model system. Annual Meeting ASTRO, Philadelphia, PA, 2006

\section{Other abstracts:}

I. W. Davidson, G. Kari, B. Daroczi, U. Rodeck, A. Dicker. Knock down of p53 suppresses radiation-induced malformations and zebrafish embryo survival. Radiation Research Annual Meeting, Denver, CO, 2005

II. G. Kari, A.Y. Zengin, B. Daroczi, A. Ryan, U. Rodeck, A.P. Dicker. Modulation of the radiation response of zebrafish embryos by targeting the VEGFR2 tyrosine kinase using ZD6474. Annual Meeting AACR-EORTC-NCI, Prague, Czech Republic, 2006

III. T.N. Showalter, B. Daroczi, R. Halko, Y. Liu, N. Marrero, X. Xu, A.P. Dicker, P.R. Wachsberger. ZD6474 enhances radiation therapy in human glioblastoma xenografts which contain the EGFR vIII mutation or overexpress wtEGFR. Radiation Research Society, Boston, MA, 2008

IV. G. Kari, B. Daroczi, A.P. Dicker, T. Force, U. Rodeck. Molecular pathways of cardiomyocyte apoptosis upon glycogen synthase kinase 3 (GSK-3) $\alpha$ inhibition. $4^{\text {th }}$ Annual Postdoctoral Research Symposium. Thomas Jefferson University, Philadelphia, PA, 2009

V. P.R. Wachsberger, T.N. Showalter, B. Daroczi, A.P. Dicker. Antitumor activity of the receptor tyrosine kinase inhibitors, vandetanib and cediranib combined with temozolomide and radiotherapy in a U87 xenograft model of human glioblastoma transfected with wildtype EGFR. AACR Annual Meeting, Denver, CO, 2009

VI. P.R. Wachsberger, T.N. Showalter, Yi Liu, B. Daroczi, A.P. Dicker. Effect of vandetanib and cediranib combined with temozolomide and radiotherapy in EGFR-expressing GBM tumors. Radiation Research Society Annual Meeting, Savannah, GA, 2009 


\section{TABLE OF CONTENTS}

ABBREVIATIONS

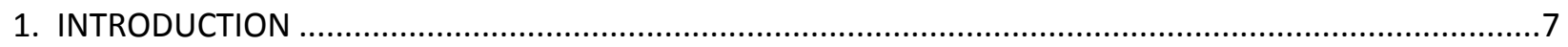

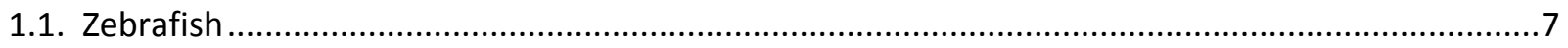

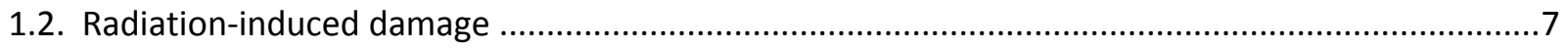

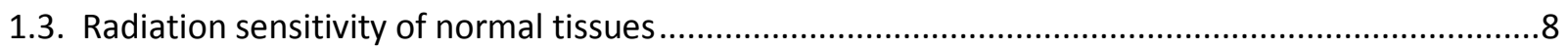

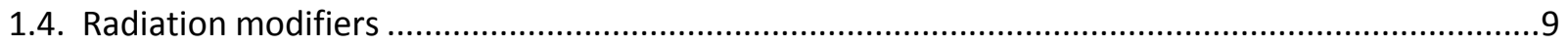

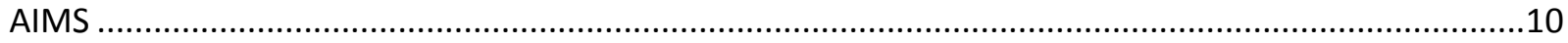

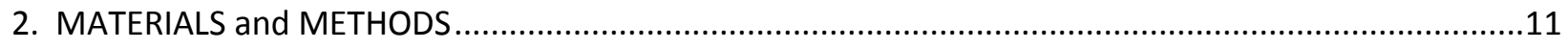

2.1. DF-1, the free radical scavenger-type radioprotector...............................................................11

2.2. Direct inhibitors of NF-KB and proteasome inhibitors .............................................................

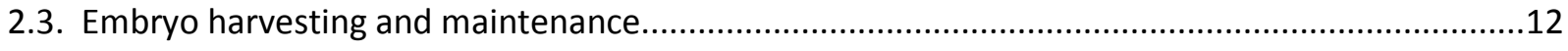

2.4. Radiation exposure and drug treatments ...............................................................................12

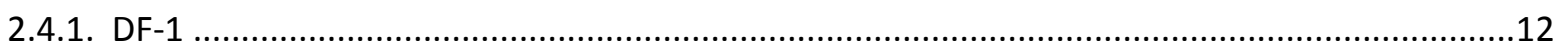

2.4.2. Manganese superoxide dismutase mimetics ........................................................................13

2.4.3. Direct inhibitors of NF-KB and proteasome inhibitors ......................................................13

2.5. Analysis of treatment effects on zebrafish morphology and survival.........................................14

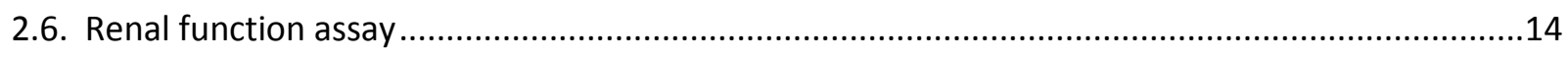

2.7. Histopathology and evaluation of embryos treated with DF-1 ................................................15

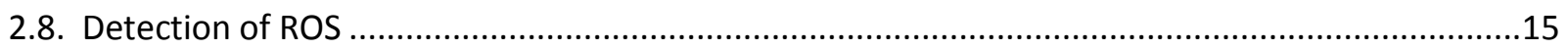

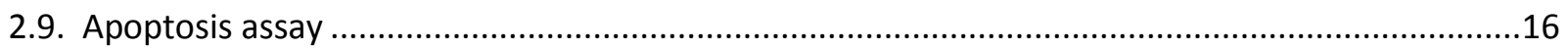

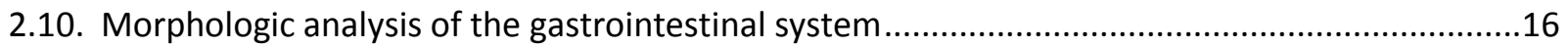

2.11. Histopathology and evaluation of tissue morphology in zebrafish embryos treated with either

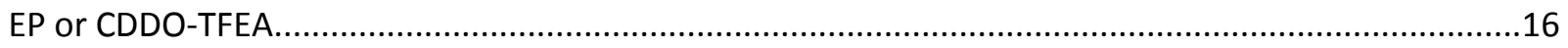

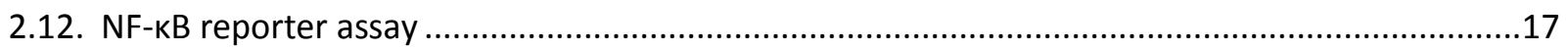

2.13. Reverse transcription polymerase chain reaction (RT-PCR) analysis ......................................17

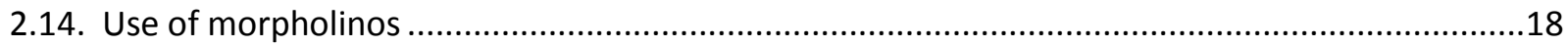

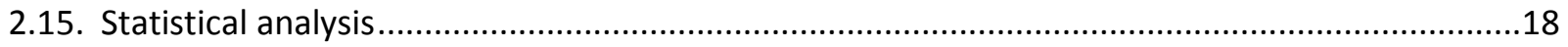

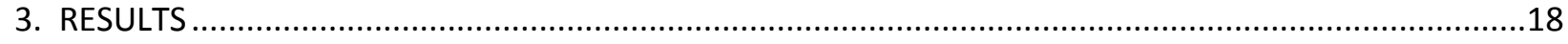

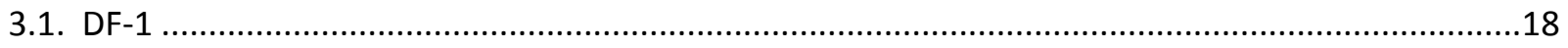

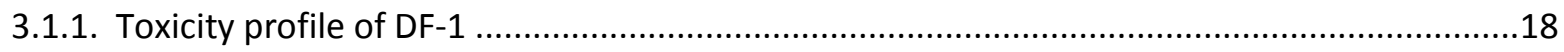

3.1.2. Effect of DF-1 on survival of zebrafish embryos exposed to ionizing radiation ......................18 
3.1.3. DF-1 alleviates radiation-induced defects in midline development ...................................20

3.1.4. DF-1 attenuates radiation-induced renal function defects ...............................................21

3.1.5. Reduction of ROS in irradiated zebrafish embryos treated with DF-1 .................................23

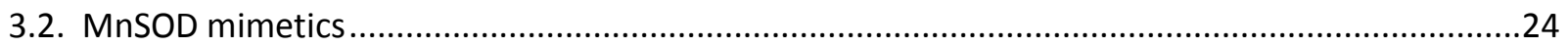

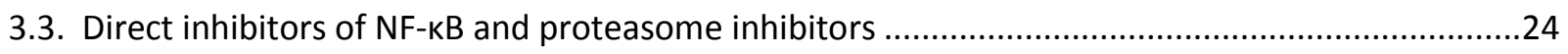

3.3.1. Proteasome inhibitors radiosensitize zebrafish embryos ....................................................24

3.3.2. Radiation protection of zebrafish embryos by the NF-kBp65 inhibitor ethyl pyruvate...........29

3.3.3. The IKK inhibitor CDDO-TFEA mitigates radiation effects in zebrafish embryos .....................32

3.3.4. Organ-specific radiation protection by CDDO-TFEA and EP ...............................................34

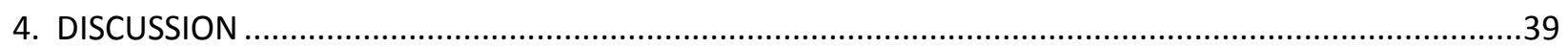

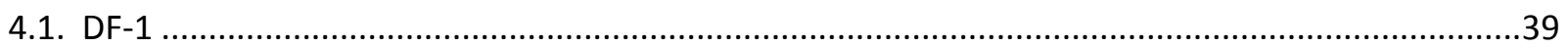

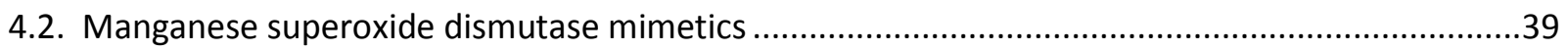

4.3. Direct inhibitors of NF-kB and proteasome inhibitors ….........................................................39

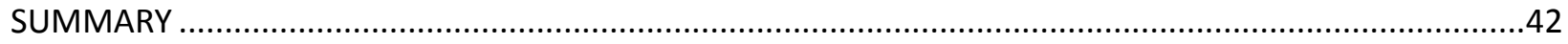

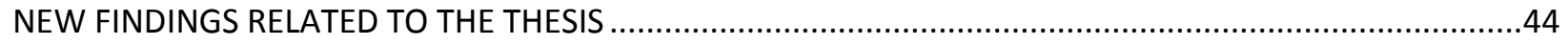

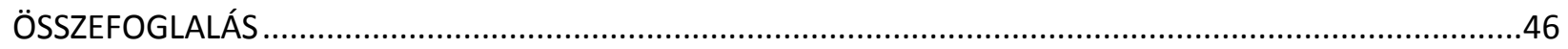

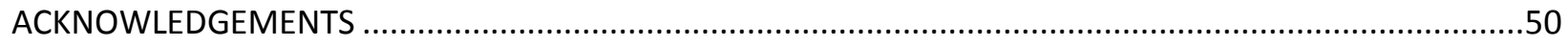

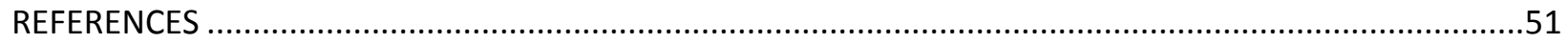




\section{ABBREVIATIONS}

AO: acridine orange

bZIP: basic leucin zipper

CNS: central nerveous system

cup: curly-up phenotype characterized by dorsal curvature of the body axis

DMSO: dimethyl sulphoxide

dpf: days post-fertilization

EP: ethyl pyruvate

hpf: hours post-fertilization

IKK $\beta$ : IкB kinase $\beta$

IR: ionizing radiation

LD50: lethal dose 50

LET: linear energy transfer

MO: morpholino

MnSOD: manganese superoxide dismutase

NF-кB: nuclear factor kappa B

Nrf2: nuclear factor erythroid 2-related factor 2

OER: oxygen enhancement ratio

PLA $_{2}$ : phoshpholipase A2

ROS: reactive oxygen species

RT-PCR: reverse transcription polymerase chain reaction

TMZ: temozolomide

TNF- $\alpha$ : tumor necrosis factor-alpha 


\section{INTRODUCTION}

\subsection{Zebrafish}

Zebrafish embryos (Danio rerio) are emerging as a powerful vertebrate model system for research. Zebrafish embryos offer several important advantages compared to cell cultures or other conventional in vivo experimental animal models: high fecundity, high number of zebrafish progeny, easy upkeep at minimal cost, large sample sizes, and availability of many conventional cell culture techniques. The transparency of the embryo permits a visual observation of the ex utero development. There is high similarity between zebrafish and mammals, and the entire zebrafish genome is sequenced [1] [2]. The organs including the gut and the vasculature are in place by 48 hours post fertilization (hpf). Zebrafish embryos are permeable to small molecules, drugs, dyes as well as peptides, and can be transfected to express genes in a tissue-specific manner. Knockdown of individual mRNAs is easily achieved by morpholino antisense oligodeoxinucleotides.

In addition, we have established zebrafish embryos as an in vivo vertebrate system to evaluate toxic effects of ionizing radiation (IR) and modifiers of IR.

\subsection{Radiation-induced damage}

The mechanisms leading to the deleterious effects of ionizing radiation are multifactorial.

IR can cause damage through energy deposition. Radiation can damage cells directly and indirectly. Many molecules in cells will be altered due to direct energy deposition or because of indirect effects as a consequence of energy transfer from one molecule to another. With low LET (linear energy transfer) radiation, as photons (gamma-or x-ray), mostly indirect effects occur, leading to single strand breaks. Charged particles, such as protons and heavy ions, can cause direct damage to cancer cell DNA through high LET and have an antitumor effect independent of tumor oxygen supply because these particles act mostly via direct energy transfer, usually causing double-strand DNA breaks.

The interactions between low LET radiation and cells result in energy deposition in the tissues, generating free radicals. Free radicals derive from water in cells, which then damage the macromolecules. The medical use of ionizing radiation can cause a variety of side effects during 
treatment (acute side effects) due to inflammatory cytokine release, in the months or years following treatment (long-term side effects) as a consequence of cell death or after re-treatment (cumulative side effects).

Tissue damage associated with inflammatory changes often limits the dose of ionizing radiation that can be safely delivered during radiation therapy. The gastrointestinal tract is particularly sensitive to radiation. A well-known example of this is inflammation of the oral mucosa or the intestinal lining following chemo - and/or radiotherapy [3]. A hallmark of IR-associated inflammation is the increased liberation of pro-inflammatory cytokines including TNF- $\alpha$ and IL6, both locally and systematically [4]. In contrast to intracellular regulators of the DNA damage response, these and other inflammatory mediators act in a paracrine fashion affecting diverse cell types in the tissue microenvironment or even at a distance [5].

\subsection{Radiation sensitivity of normal tissues}

Cells are intrinsically sensitive to irradiation. The nature, severity, and longevity of radiation effects depend on the cell type, proliferation, intracellular and microenvironmental factors as well as on the type of radiation, dose, and fractionation. Rapidly dividing and immature cells are more sensitive to ionizing radiation than differentiated cells, with the exception of lymphocytes. Bergonie and Tribondeau defined radiation sensitivity based on the mitotic activity. Rubin and Casarett classified five categories of cell populations using histological signs of cell death, as follows:

\begin{tabular}{|c|c|c|c|}
\hline Cell type & Characteristics & Examples & Radiation sensitivity \\
\hline Vegetative intermitotic cells & $\begin{array}{l}\text { Rapidly and regularly dividing, } \\
\text { undifferentiated cells which do not } \\
\text { divide between divisions }\end{array}$ & $\begin{array}{l}\text { erythroblasts, basal cells of } \\
\text { epidermis, crypt cells of intestine, } \\
\text { type A spermatogonia }\end{array}$ & \multirow[t]{5}{*}{ High } \\
\hline Differentiating intermitotic cells & $\begin{array}{l}\text { Actively dividing, more differentiated } \\
\text { cells which divide between divisions }\end{array}$ & $\begin{array}{ll}\text { myelocytes, } & \text { intermediate } \\
\text { spermatogonia } & \end{array}$ & \\
\hline Multipotential connective tissue cells & Irregularly dividing cells & endothelial cells, fibroblasts & \\
\hline Reverting postmitotic cells & $\begin{array}{l}\text { Variably differentiated cells which do } \\
\text { not normally divide but they retain the } \\
\text { capability of division }\end{array}$ & $\begin{array}{l}\text { lymphocytes, parenchymal cells } \\
\text { of liver, kidney, pancreas }\end{array}$ & \\
\hline Fixed post-mitotic cells & $\begin{array}{l}\text { Highly differentiated cells which do not } \\
\text { divide }\end{array}$ & $\begin{array}{l}\text { red blood cells, nerve cells, } \\
\text { muscle cells, spermatozoa }\end{array}$ & \\
\hline
\end{tabular}


Radiation sensitivity to low LET radiation also depends on the oxygen level of the tissue. The more oxygenated the more sensitive the tissue is. Radiation sensitivity reaches its maximum at an oxygen tension of $30 \mathrm{mmHg}$ and does not significantly change by increasing the oxygen tension. Since normal tissues have an oxygen tension ranging from 40 to $120 \mathrm{mmHg}$; therefore, the oxygen tension does not interfere with the radiation sensitivity in healthy normal tissues.

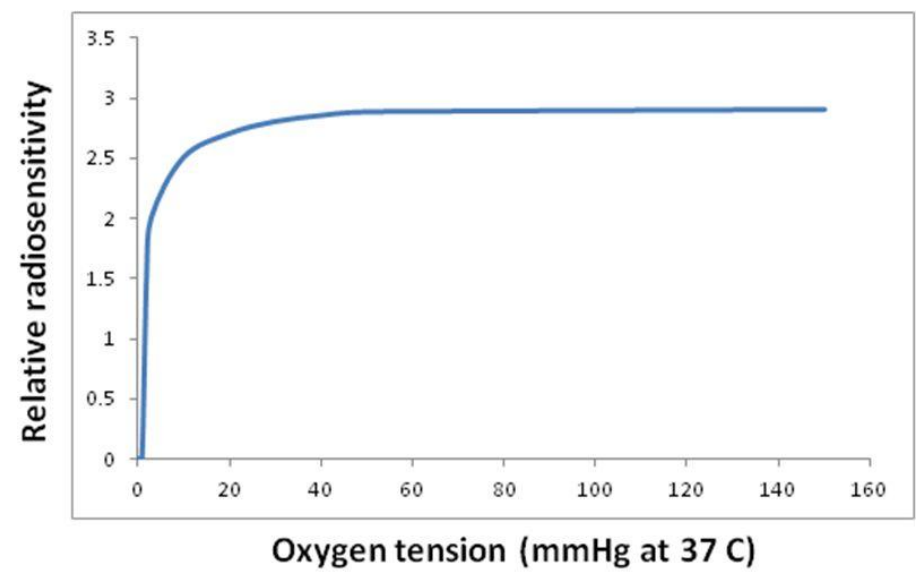

Dependence of radiosensitivity on oxygen tension

\subsection{Radiation modifiers}

There is a great interest in developing radioprotectors to prevent normal tissue toxicity during chemo- and/or radiotherapy or nuclear accidents. On the other hand, the most successful way to treat certain cancers is through multimodality therapy. In one of our studies, we put emphasis on the postoperative management of patients with primary glioblastoma multiforme. Groups of patients treated with combinations of different therapeutic modalities were compared to each other and evaluated [6]. Temozolomide (TMZ) was used as a chemotherapeutic agent. The alkylating agent TMZ, when administered simultaneously with radiation therapy, can improve the effectiveness of treatment by making tumor cells more sensitive to radiation. At the same time, sparing healthy tissues of the central nervous system (CNS) from radiation injury and increasing radiation tolerance in normal tissues of the CNS play an essential role in improving the therapeutic index. To develop approaches to prophylaxis/protection, mitigation and treatment of radiation injuries, appropriate models are needed, which integrate the complex events that can occur in the organism exposed to radiation. While the spectrum of agents in clinical use or preclinical development is limited, new research findings promise improvements in survival after 
whole-body irradiation and reductions in the risk of adverse effects of radiotherapy. The approaches include protective agents that act on the initial radiochemical events, mitigating agents that prevent or reduce progression of the radiation damage, and agents that facilitate recovery from radiation injuries.

Ideally, radioprotectors can prevent normal tissues from the deleterious effects of ionizing radiation; whereas radiation sensitizers can make tumor cells more sensitive to radiation, enhancing the efficacy of radiotherapy. Generally, radioprotectors work on low linear energy transfer and only have a protective effect as great as the oxygen enhancement ratio (OER). Mostly, radioprotectors afford protection against ionizing radiation when given prophylactically. There are a few main groups of radioprotectors:

- One of the groups involves those agents that can reduce the amount of oxygen by causing vasoconstriction and relative hypoxia, such as cyanide, epinephrine, histamine, or serotonin. However, these agents are not suitable for radioprotection in clinical settings.

- The other group consists of free radical scavengers: Vitamins C and E, intracellular MnSOD, and compounds containing sulfhydryl (-SH) groups, such as glutathione and cysteine, which are well-known antioxidants.

The above-mentioned two groups can mainly work by opposing the oxygen effect.

- Whereas other agents can provide radioprotection by targeting molecular pathways.

\begin{abstract}
AIMS
The aim of our study was to assess agents that can modify the radiation response. We evaluated whether the agents under investigation could prevent normal tissues from the deleterious effects of total body irradiation and whether any of these compounds could mitigate the deleterious effects

of irradiation.
\end{abstract}




\section{MATERIALS and METHODS}

\subsection{DF-1, the free radical scavenger-type radioprotector}

DF-1 (C-Sixty, Inc., Houston, TX) is a hydrophilic antioxidant based on the hollow nanostructure of fullerenes.

Fullerenes represent a family of molecules composed of 20,40,60, 70, or 84 carbon atoms. Fullerenes have the potential to scavenge reactive oxygen species (ROS), including hydrogen peroxide, hydroxyl radicals, hydroperoxy radicals, and superoxide, but their basic structures are not water-soluble without modification. C60 fullerene is the most frequently used member of this family [7]. DF-1 is a C60 fullerene derivative (dendrofullerene) that contains 18 carboxylic groups to enhance water solubility [8]. DF-1 has been known to exert powerful antioxidant effects in vitro [9].

\subsection{Direct inhibitors of NF- $\kappa B$ and proteasome inhibitors}

The nuclear factor $\kappa \mathrm{B}(\mathrm{NF}-\kappa \mathrm{B})$ family of transcription factors represents a diverse and shared signaling mechanism activated during cell stress responses [10]. Deregulated NF-кB signaling has been implicated in the malignant phenotype and treatment resistance of select tumor forms

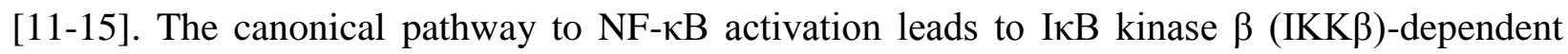

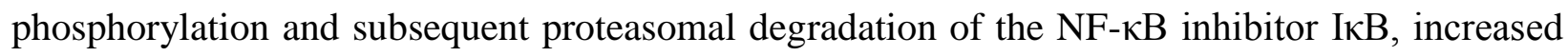
nuclear presence of NF-kB dimers, and enhanced NF-kB-dependent transcriptional activity [10]. Whole-body radioprotection through anti-inflammatory agents has been shown in animal models. Specifically, certain triterpenoids (CDDO and derivatives thereof) have been shown to selectively protect normal mouse tissues against the deleterious effects of ionizing radiation [16]. Furthermore, EP, a derivative of the end product of glycolysis, similarly protects normal cells against the deleterious effects of radiation both in vitro and in mice [17].

Both CDDO-TFEA and EP inhibits activation of NF- $\kappa B$. EP inhibits NF- $\kappa B$ signaling through direct molecular interaction with a reactive cysteine of the p65 subunit of NF- $\mathrm{KB}$ [18] whereas CDDO-TFEA binds to a reactive cysteine (Cys 179) of IKK $\alpha$, thus inhibiting its kinase activity 
[19]. However, these compounds also target other signaling molecules and pathways of potential relevance to the radiation response, including signal transducers and activators of transcription 3 and Jaks [20, 21].

Additionally, four pharmacologic IKK inhibitors with different modes of action were also tested. In addition to these agents, proteasome inhibitors were also evaluated. They have been shown to inhibit NF-кB-dependent transcription, and one of these (PS-341; Bortezomib; VELCADE) has been approved for clinical use in patients with multiple myeloma [22, 23].

\subsection{Embryo harvesting and maintenance}

Wild-type zebrafish were mated in embryo collection tanks. Viable embryos were washed and plated at the one- to two-cell developmental stage and kept under normoxic conditions at 28.5 ${ }^{\circ} \mathrm{C}$. Embryo medium was changed at every 24 hours. In select experiments, embryos (24 hpf) were dechorionated by placement in embryo medium supplemented with $50 \mu \mathrm{g} / \mathrm{mL}$ pronase (Sigma) for approximately $10 \mathrm{~min}$ at room temperature, then gently agitated with a plastic pipette until the embryos were liberated from the disrupted chorions. After dechorionation, the embryos were rinsed thoroughly with embryo medium, and placed in fresh embryo medium.

\subsection{Radiation exposure and drug treatments}

\subsubsection{DF-1}

DF-1 was dissolved in embryo medium containing no more than $0.4 \%$ dimethyl sulphoxide (DMSO). Embryo medium containing 0.4\% DMSO was used as a vehicle control in the DF-1 experiments since DMSO is known to possess radioprotective effects. Amifostine was used as a positive control in select experiments and was used at $4 \mathrm{mmol} / \mathrm{L}$, which is the efficient concentration previously described for radioprotection [24]. Unless stated otherwise, embryos were exposed to a single dose of ionizing radiation ranging dose from 0 to $40 \mathrm{~Gy}$ at $24 \mathrm{hpf}$ using

either a ${ }^{137} \mathrm{Cs}$ radiation source or an X-ray machine. DF-1 toxicity analysis was conducted using a dilution series of $0,10,100$, and $1000 \mu \mathrm{mol} / \mathrm{L} \mathrm{DF}-1$ in the absence of radiation. To determine modulation of radiation induced toxicity, DF-1 was added at $100 \mu \mathrm{mol} / \mathrm{L}$ to embryos for 3 hours and 30,15 , or 5 minutes before radiation exposure and 5, 15, or 30 minutes after radiation 
exposure. After irradiation, zebrafish embryos were kept at $28.5 \mathrm{C}$ for up to 7 days post fertilization to monitor effects of treatments on survival, morphology, and organ-specific toxicity.

\subsubsection{Manganese superoxide dismutase mimetics}

We used zebrafish embryos to explore the putative radioprotective effects of two manganese superoxide dismutase (MnSOD) mimetics; M40403 (ActivBiotics, formerly Metaphore, Lexington, MA) and MnTE-2-PyP5+ (Duke University). M40403 is a stable, non-peptidyl, synthetic manganese superoxide dismutase mimetic (MnSOD) with a low molecular weight, which eliminates superoxide anions $\left(\mathrm{O}_{2}^{-}\right)$without interfering with other radicals known to be involved in inflammatory responses [25]. MnTe-2-PyP5+ is a synthetic SOD mimetic, which was synthesized as described by Batinic-Haberle et al. [26].

Radioprotection was assessed by determining drug effects on IR-associated mortality. To evaluate in vivo toxicity of these agents, zebrafish embryos at 24 hours post fertilization (hpf) were exposed to log-fold dilution series until $144 \mathrm{hpf}$. Based on the toxicity profiles, zebrafish embryos (24 hpf) were exposed to IR (20 Gy) with either MnTE-2-PyP5+ (2.5 $\mu \mathrm{M})$ or M40403 $(100 \mu \mathrm{M})$ or Amifostine $(4 \mathrm{mM})$ administered $3 \mathrm{~h}$ prior to ionizing radiation. Embryos were evaluated at 24-h intervals until $168 \mathrm{hpf}$ for viability and radiation-induced gross morphological alterations.

\subsubsection{Direct inhibitors of NF- $\mathrm{KB}$ and proteasome inhibitors}

Pharmacologic agents (EP; CDDO-TFEA; IKK inhibitors: IKK Inhibitor 2 (Wedelolactone), IKK Inhibitor 3 (BMS-345541), IKK-2 Inhibitor 4 and IKK-2 Inhibitor 5 (IMD-0354); MG132; PS-341, and Lactacystin) were dissolved in EM containing <0.1\% DMSO. EM was used as a vehicle control in all experiments. Unless stated otherwise embryos were exposed to ionizing radiation ranging in dose from 0-20 Gy at 24 hpf using an X-ray machine (Gulmay Medical, Bethel, CT) or a ${ }^{137} \mathrm{Cs}$ radiation source.

Toxicity analyses for EP $(\leq 10 \mathrm{mM})$, CDDO-TFEA $(\leq 10 \mu \mathrm{M})$, PS-341 $(\leq 10 \mu \mathrm{M})$, MG132 $(\leq 50$ $\mu \mathrm{M})$ or Lactacystin $(\leq 10 \mu \mathrm{M})$ were conducted by monitoring survival and development of 
zebrafish embryos for 7 days in the absence of radiation. To determine modulation of radiationinduced toxicity, EP $(1 \mathrm{mM})$ or CDDO-TFEA $(1 \mu \mathrm{M})$ was added to embryos either $1 \mathrm{~h}$ before or up to $3 \mathrm{~h}$ after radiation exposure at $24 \mathrm{hpf}$. The proteasome inhibitors were added to zebrafish embryos $1 \mathrm{~h}$ prior to IR. After irradiation, zebrafish embryos were maintained at $28.5^{\circ} \mathrm{C}$ for up to 7 days post fertilization (dpf) to monitor effects of treatments on survival, morphology and organ-specific toxicity.

\subsection{Analysis of treatment effects on zebrafish morphology and survival}

Dechorionated embryos at $72 \mathrm{hpf}$ were anesthetized with $1: 100$ dilution of $4 \mathrm{mg} / \mathrm{mL}$ tricaine methanesulfonate and immobilized by placing them on 3\% methylcellulose on a glass depression slide. Morphology was assessed visually using a light transmission microscope at 40 to 100X magnification, and representative images were recorded. Similarly, survival of embryos was assessed visually at 24-hour intervals up to $168 \mathrm{hpf}$ by light microscopy. The criterion for viability was the presence of cardiac contractility.

\subsection{Renal function assay}

Clearance of tetramethylrhodamine-labeled, $10-\mathrm{kDa}$ dextran from the cardiac area was determined. Briefly, zebrafish embryos at $24 \mathrm{hpf}$ were exposed to ionizing radiation and maintained in embryo medium. At $72 \mathrm{hpf}$, zebrafish embryos were anesthetized using a 1:100 dilution of $4 \mathrm{mg} / \mathrm{mL}$ tricaine methanesulfonate and dorsally positioned on $3 \%$ methylcellulose gel. Tetramethylrhodamine-labeled, 10-kDa dextran (Molecular Probes, Eugene, OR) was injected into the cardiac venous sinus; embryos were kept at $28.5^{\circ} \mathrm{C}$ and imaged 1 and 24 hours following microinjection. The average fluorescence emission at $590 \mathrm{~nm}$ following excitation at $570 \mathrm{~nm}$ was detected at the center of the cardiac area, and the relative intensity was measured using a Leica microscope. Images were transformed into grayscale and evaluated with NIH ImageJ software as described by Hentschel et al. [27]. 


\subsection{Histopathology and evaluation of embryos treated with DF-1}

Zebrafish embryos were evaluated histopathologically for morphologic alterations of ionizing radiation exposure and the potential radioprotective effects of DF-1. Briefly, embryos at $4 \mathrm{dpf}$ were exposed to 0,20 , or 20 Gy plus DF-1 $(100 \mu \mathrm{mol} / \mathrm{L})$ given 3 hours before radiation exposure. Following sacrifice using a 1:100 dilution of $4 \mathrm{mg} / \mathrm{mL}$ tricaine methanesulfonate (Sigma), embryos were initially fixed and preserved in Davidson's solution for 24 hours and then rinsed and placed in $10 \%$ neutral buffered formalin for a minimum of 4 days. All specimens were processed in graded alcohol (70-100\%), cleared twice at 10 minutes each in Clear-Rite 3, and infiltrated with paraffin (Paraplast, McCormick Scientific, St. Louis, MO). Sections were embedded in paraffin, and transverse whole-body sections (4-6 $\mu \mathrm{m}$ thickness; 100-120 sections per fish) were made (Leica RM 2135 rotary microtome, Leica, Inc.) serially from the rostral aspect of the head to the mid-trunk region of each fish. All sections were stained with modified Mayer's hematoxylin 2 and eosin-Y, mounted on glass slides, and coverslipped. Sections were examined by light microscope (Olympus BX51, Olympus) at 4 to $40 \mathrm{X}$ magnification, and representative images were recorded using a SPOT camera and SPOT Advanced software (SPOT Diagnostic Instruments).

\subsection{Detection of ROS}

Production of ROS was measured in dechorionated whole zebrafish embryos at $24 \mathrm{hpf}$ in 96-well plates. Embryos (one per well) were treated with either vehicle $(\leq 0.4 \%$ DMSO in embryo medium) or the agent to be tested (namely DF-1 at $100 \mu \mathrm{mol} / \mathrm{L}$ or $\mathrm{EP}$ at $1 \mathrm{mmol} / \mathrm{L}$ or CDDOTFEA at $1 \mu \mathrm{mol} / \mathrm{L}$ ) in the presence of 5-(and-6)-chloromethyl 2,7-dihydrodichlorofluorescein diacetate (CM-H2DCFA; Molecular Probes) followed by radiation exposure at $24 \mathrm{hpf}$. Zebrafish embryos were incubated in EM containing one of the above-mentioned agents before ionizing radiation at 24 hours; the fluorescent dye CM-H2DCFA $(500 \mathrm{ng} / \mathrm{mL})$ was added 1 hour before radiation exposure. The average fluorescence emission at $530 \mathrm{~nm}$ following excitation at $490 \mathrm{~nm}$ was detected immediately and 2 hours after ionizing radiation exposure using a microplate fluorescent reader. To account for radiation-induced ROS in the embryo medium results were corrected by subtraction of values obtained in wells not containing fish in the presence and absence of pharmacologic agents. 


\subsection{Apoptosis assay}

Quantitative apoptosis measurements were performed by staining with the vital dye acridine orange (AO) that permeates dying cells to bind to chromatin. Zebrafish embryos were incubated for $1 \mathrm{~h}$ in EM containing one of the radiation modifiers and irradiated with $20 \mathrm{~Gy}$ at $24 \mathrm{hpf}$. Six hours later, zebrafish embryos were manually dechorionated and stained for 15 minutes using 5 $\mu \mathrm{g} / \mathrm{mL}$ of Acridine Orange dye (Sigma) and rinsed five times with EM [28]. Zebrafish embryos were then imaged with QIMAGING camera and iVision software, and the images were then analyzed using ImageJ software.

\subsection{Morphologic analysis of the gastrointestinal system}

The functional and morphologic integrity of the developing gastrointestinal system was assessed in zebrafish embryos using PED6, a fluorescent reporter of phospholipase A2 ( $\left.\mathrm{PLA}_{2}\right)$ activity. To evaluate intestinal lipid processing, PED6 (Molecular Probes, Eugene, OR) was added to zebrafish at day 5 and images were taken at day 6 with the average fluorescence emission at 540 $\mathrm{nm}$ following excitation at $505 \mathrm{~nm}$. PED6 is a fluorogenic substrate for PLA $\mathrm{A}_{2}$, which contains a BODIPY FL dye-labeled acyl chain and a dinitrophenyl quencher group [29]. The cleavage of the dye-labeled acyl chain by PLA $_{2}$ within cells lining the intestine unquenches the dye and leads to detectable fluorescence in the lumen of the developing gastrointestinal tract. PED6 was added to zebrafish embryos at $5 \mathrm{dpf}$ followed by imaging the fish at $6 \mathrm{dpf}$ with the average fluorescence emission at $540 \mathrm{~nm}$ excitation at $505 \mathrm{~nm}$. Images were taken at $6 \mathrm{dpf}$ using a Leica microscope and analyzed using the ImageJ software.

\subsection{Histopathology and evaluation of tissue morphology in zebrafish embryos treated with either EP or CDDO-TFEA}

Zebrafish embryos were evaluated histopathologically for morphologic alterations induced by radiation exposure and potential radioprotective effects of EP and CDDO-TFEA with special emphasis on the gastrointestinal morphology. Briefly, embryos at $24 \mathrm{hpf}$ were exposed to 0 or 12 Gy in the presence or absence of either CDDO-TFEA or EP administered $1 \mathrm{~h}$ prior to ionizing radiation. Embryos were sacrificed, fixed by immersion in $4 \%$ paraformaldehyde for $24 \mathrm{~h}$, and then rinsed and placed in 10x PBS for another $24 \mathrm{~h}$. Sections were embedded in paraffin, and 
coronal, transverse, and sagittal whole-body sections (4 $\mu \mathrm{m}$ thickness) were generated. All sections were stained with $\mathrm{H} \& \mathrm{E}$, mounted on glass slides, and examined by light microscope; representative images were taken using a QIMAGING camera and iVision software.

\subsection{2. $\mathrm{NF}-\kappa \mathrm{B}$ reporter assay}

$\mathrm{NF}-\kappa \mathrm{B}$ reporter assay was done as described by Ren et al. [30] with minor modifications. HeLa cells were seeded at $7.5 \times 10^{4} / \mathrm{ml}$ in DMEM medium supplemented with $10 \%$ fetal bovine serum. The cells were co-transfected with the pSEAP2- NF- $\mathrm{BB}$ vector (BD BioSciences) encoding a secreted form of human placental alkaline phosphatase driven by a NF- $\kappa$ B-responsive promoter and a $\beta$-galactosidase expression vector for control purposes. Forty-eight hours post transfection, different NF- $\kappa \mathrm{B}$ inhibitors (Velcade, $0.5 \mu \mathrm{M}$; MG-132, $5 \mu \mathrm{M}$; EP, 1mM; CDDO-TFEA, $1 \mu \mathrm{M}$ ) were added to the cells in serum-free media for 24 hours. NF- $\kappa B$-dependent transcription in the absence and presence of recombinant TNF- $\alpha$ (10 ng/ml; R\&D Systems) was determined 72 hours post transfection using the Great EscAPe SEAP Reporter System 3, which is based on detection of secreted alkaline phosphatase in cell supernatants normalized to $\beta$-galactosidase activity using the luminescent $\beta$-gal detection kit (BD Biosciences).

\subsection{Reverse transcription polymerase chain reaction (RT-PCR) analysis}

Zebrafish total RNA was isolated form 100 embryos per experimental condition at $30 \mathrm{hpf}(6 \mathrm{~h}$ post radiation) using the RNeasy mini kit (QIAGEN Sciences, Maryland, USA) and stored at -80 ${ }^{\circ} \mathrm{C}$. For reverse transcription, total RNA was annealed with Oligo(dT) primer at $70^{\circ} \mathrm{C}$ for 5 min and then incubated at $42^{\circ} \mathrm{C}$ for $1 \mathrm{~h}$. Reverse transcription reaction products were boiled for 2 min followed by incubation on ice for $2 \mathrm{~min}$ before use. Primer sequences used for amplification of bax, $m d m 2$, p21/waf-1 and $\beta$-actin zebrafish sequences are provided in Supplementary Table S1

of paper II in the appendix. PCR reaction conditions were $94{ }^{\circ} \mathrm{C}, 60{ }^{\circ} \mathrm{C}, 72{ }^{\circ} \mathrm{C}$ for $30 \mathrm{sec}$., 30 sec., 1 min., respectively and 35 cycles with 7 min. extension time after the last cycle. Thermo Fisher Scientific Taq-polymerase was used in $50 \mu \mathrm{L}$ PCR reaction mix containing $1 \mu \mathrm{L}$ RT reaction. PCR reactions were analyzed by $1.5 \%$ agarose gel electrophoresis. 


\subsection{Use of morpholinos}

Morpholino antisense oligonucleotides (MO) have commonly been used to achieve sequencespecific gene knockdown. Zebrafish embryos were injected at 1-2 cell stage with an approximately 3-5 ng MO per embryo to study signaling in developing zebrafish embryos. Control embryos were mock-injected with control MO.

\subsection{Statistical analysis}

All experiments were performed at least three times with at least 75 embryos total per experimental group. To determine statistically significant differences between groups, $\chi^{2}$-tests were performed.

\section{RESULTS}

\subsection{DF-1}

\subsubsection{Toxicity profile of DF-1}

DF-1 toxicity analysis was conducted using a dilution series of $0,10,100$, and $1,000 \mu \mathrm{mol} / \mathrm{L}$ of DF-1 in the absence of radiation. No adverse affects were noted on either survival or gross morphology throughout the concentration range tested, up to $1 \mathrm{mmol} / \mathrm{L}$ (Fig. $1 \mathrm{~A}$ ).

\subsubsection{Effect of DF-1 on survival of zebrafish embryos exposed to ionizing radiation}

We focused on the radioprotective effects of DF-1 as determined by viability assessment of irradiated zebrafish embryos pretreated with the fullerene. Embryos were exposed at $24 \mathrm{hpf}$ to either 20 or 40 Gy based on our previous observation that, at this stage of development, $20 \mathrm{~Gy}$ represents the LD50. In addition, organogenesis has commenced by $24 \mathrm{hpf}$; thus, this time point is a preferred developmental stage to assess radiation-induced effects on most major organs. DF1 given before radiation prolonged survival significantly in zebrafish embryos when exposed to either 20 or $40 \mathrm{~Gy}$. This effect was maximal at a concentration of $100 \mu \mathrm{mol} / \mathrm{L}$ (Fig. 1 B). At 40 Gy, protection was only partial, but all embryos eventually died within the observation period of up to $6 \mathrm{dpf}$ (Fig. $1 \mathrm{D})$. DF-1 (100 $\mu \mathrm{mol} / \mathrm{L})$ provided a level of radioprotection, which was similar to that provided by $4 \mathrm{mmol} / \mathrm{L}$ amifostine (Fig. $1 \mathrm{C}$ and D). 


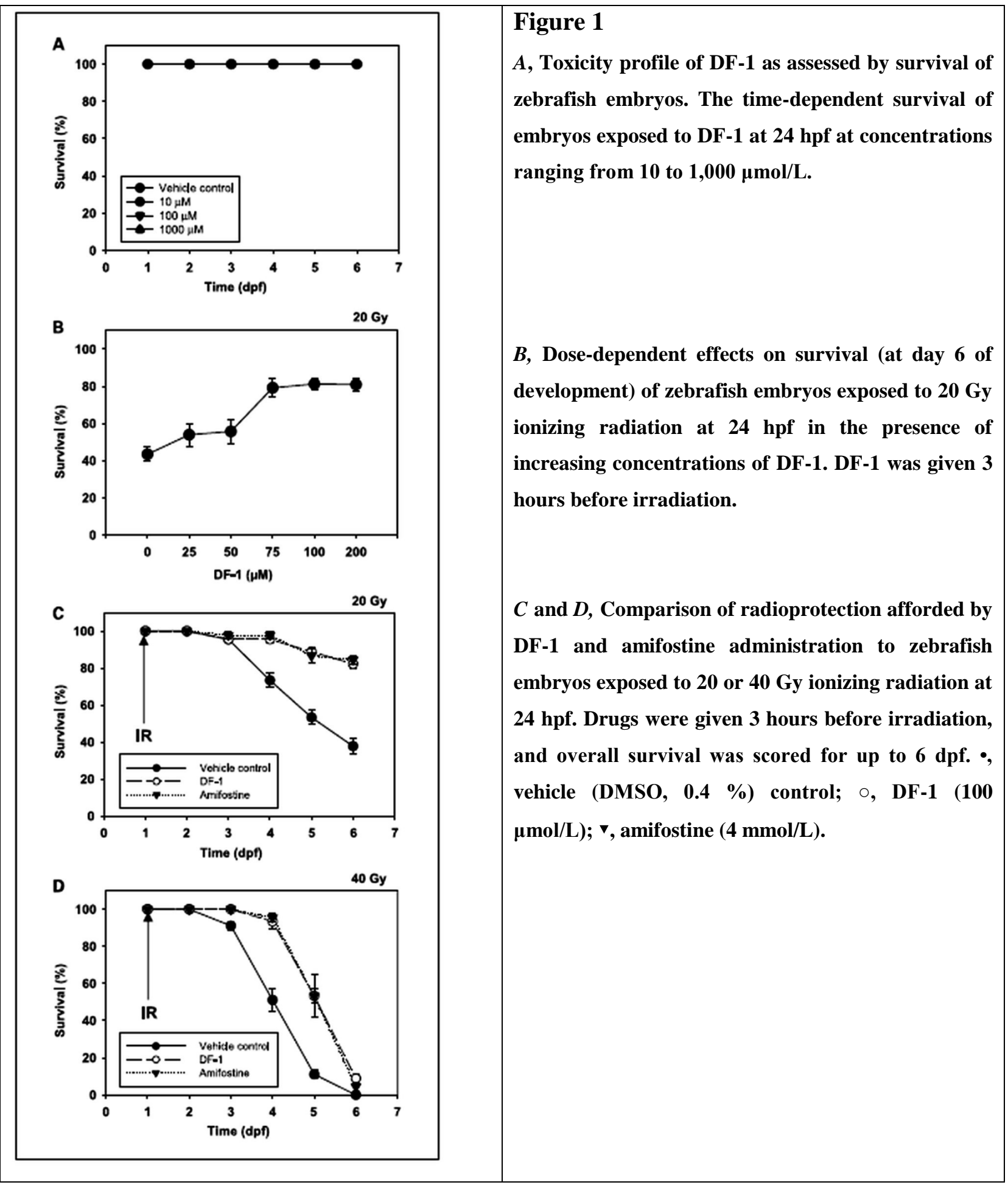

Time course experiments showed that maximal rescue of radiation-associated lethality and gross morphologic defects was achieved when DF-1 was given 3 hours, compared with 30, 15, or 5 minutes, before ionizing radiation treatment. We also assessed whether DF-1 could be used to 
mitigate radiation effects on survival when given after radiation exposure. DF-1 did not confer a survival advantage to zebrafish embryos when given 30 minutes after 20 Gy ionizing radiation exposure. However, DF-1 significantly enhanced survival when given concurrently or up to 15 minutes after irradiation (Fig. 2).

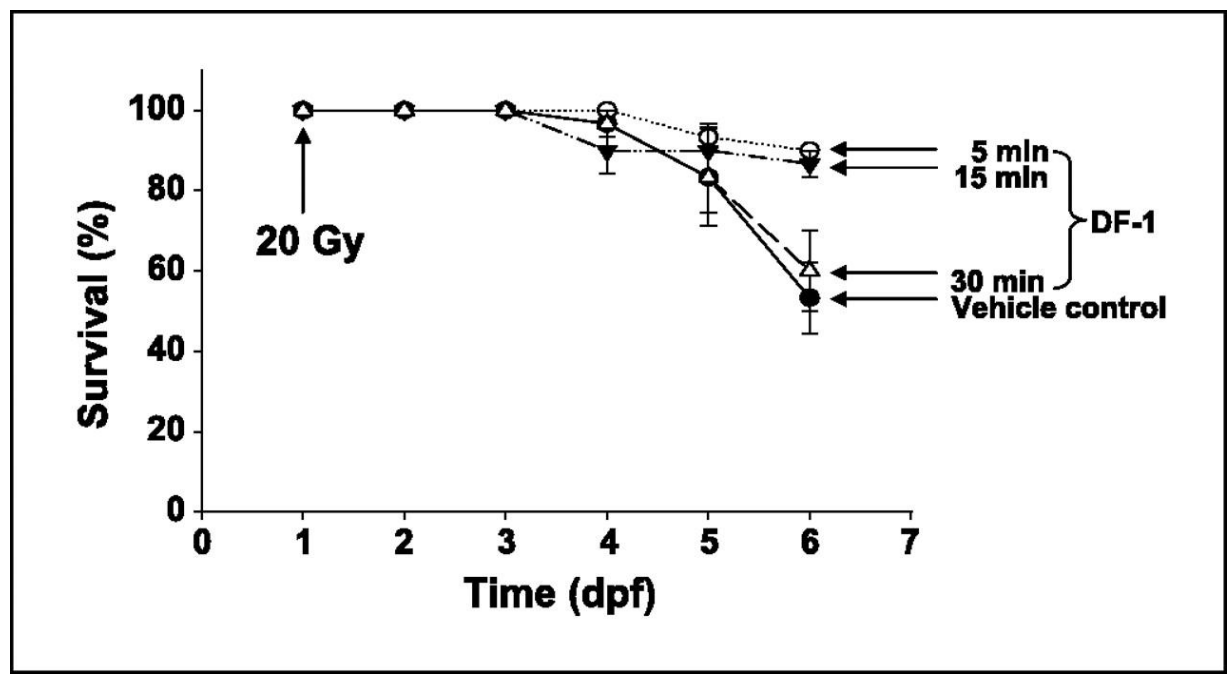

Figure 2 Mitigating effects of DF-1 on radiation-induced lethality in zebrafish embryos. DF-1 (100 $\mu \mathrm{mol} / \mathrm{L}$ ) was given 5,15 , or 30 minutes after irradiation $(20 \mathrm{~Gy}$ ), and survival was assessed for 5 days. When given 30 minutes after radiation, DF-1 did not affect embryonic survival after exposure. Vehicle control (•); $100 \mu \mathrm{mol} / \mathrm{L}$ DF-1, 5 minutes $(\circ), 15$ minutes $(\nabla)$, and 30 minutes $(\Delta)$ after irradiation.

\subsubsection{DF-1 alleviates radiation-induced defects in midline development}

To obtain a more detailed view of DF-1-mediated radioprotection, we evaluated the effects of this drug on organ-specific, radiation-induced damage. We assessed the effects of DF-1 on a commonly observed and easily scored phenotype apparent within 1 to 2 days following ionizing radiation exposure of zebrafish. This phenotype consists of dorsal curvature of the body axis previously described as "curly-up" or "cup" and ascribed to defects in midline development of zebrafish embryos [31]. Although the mechanism leading to "cup" is presently unknown, the ease with which this phenotype can be observed makes it an attractive parameter to score radiation toxicity in zebrafish embryos (Fig. 3). We observed that throughout the dose range tested, DF-1 markedly reduced the incidence of "cup". Depending on the IR dose, it either reduced the severity or abolished the dorsal curvature altogether. 


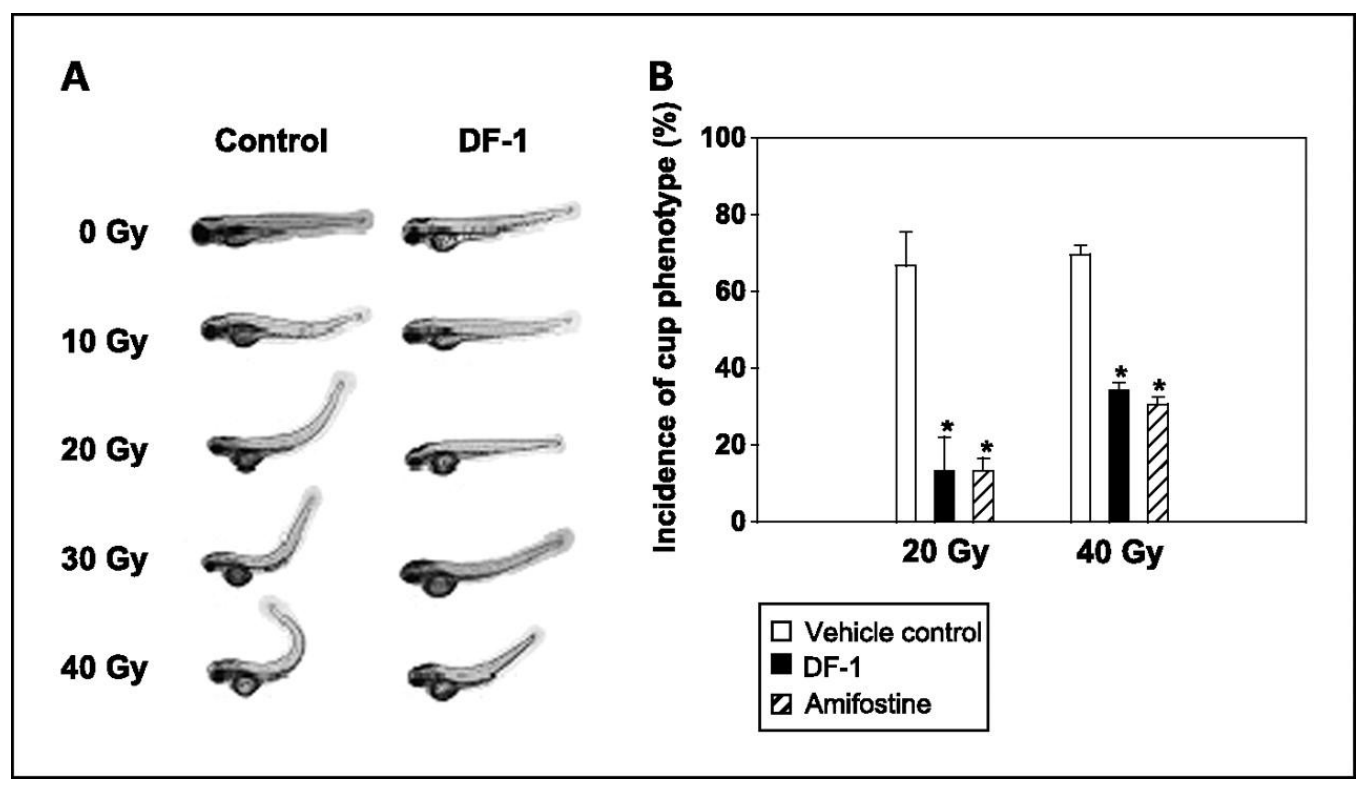

Figure 3 DF-1 protects against radiation-induced defects in midline development. Radiation-induced morphological changes in body axis were assessed at $3 \mathrm{dpf}$. $A$, Representative pictures of IR-induced dorsal curvature ("cup" phenotype) in zebrafish and attenuation of this effect by DF-1 (100 $\mu$ M) administered $3 \mathrm{~h}$ prior to IR ( $24 \mathrm{hpf})$. $B$, The bar graph shows the quantitative representation of the results after 20 or $40 \mathrm{~Gy}$ IR as indicated. Statistically significant differences $(p=0.0077)$ between control and experimental groups are indicated by asterices.

\subsubsection{DF-1 attenuates radiation-induced renal function defects}

Radiation exposure of embryos produced extensive edema in the developing fish, and this effect was reversed by DF-1 treatment. We hypothesized that this phenotype was due to impaired renal function after radiation, an effect well documented in mammals, including humans [32]. To address this issue, we used an excretory function assay, which measures clearance of a fluorescent dextran within 24 hours after injection into the cardiac venous sinus [27]. Compared with non-irradiated controls, exposure to $20 \mathrm{~Gy}$ ionizing radiation markedly reduced clearance of this agent. By contrast, pretreatment of embryos with $100 \mu \mathrm{mol} / \mathrm{L}$ DF-1 restored clearance to levels indistinguishable from those observed in non-irradiated fish embryos (Fig. 4). 


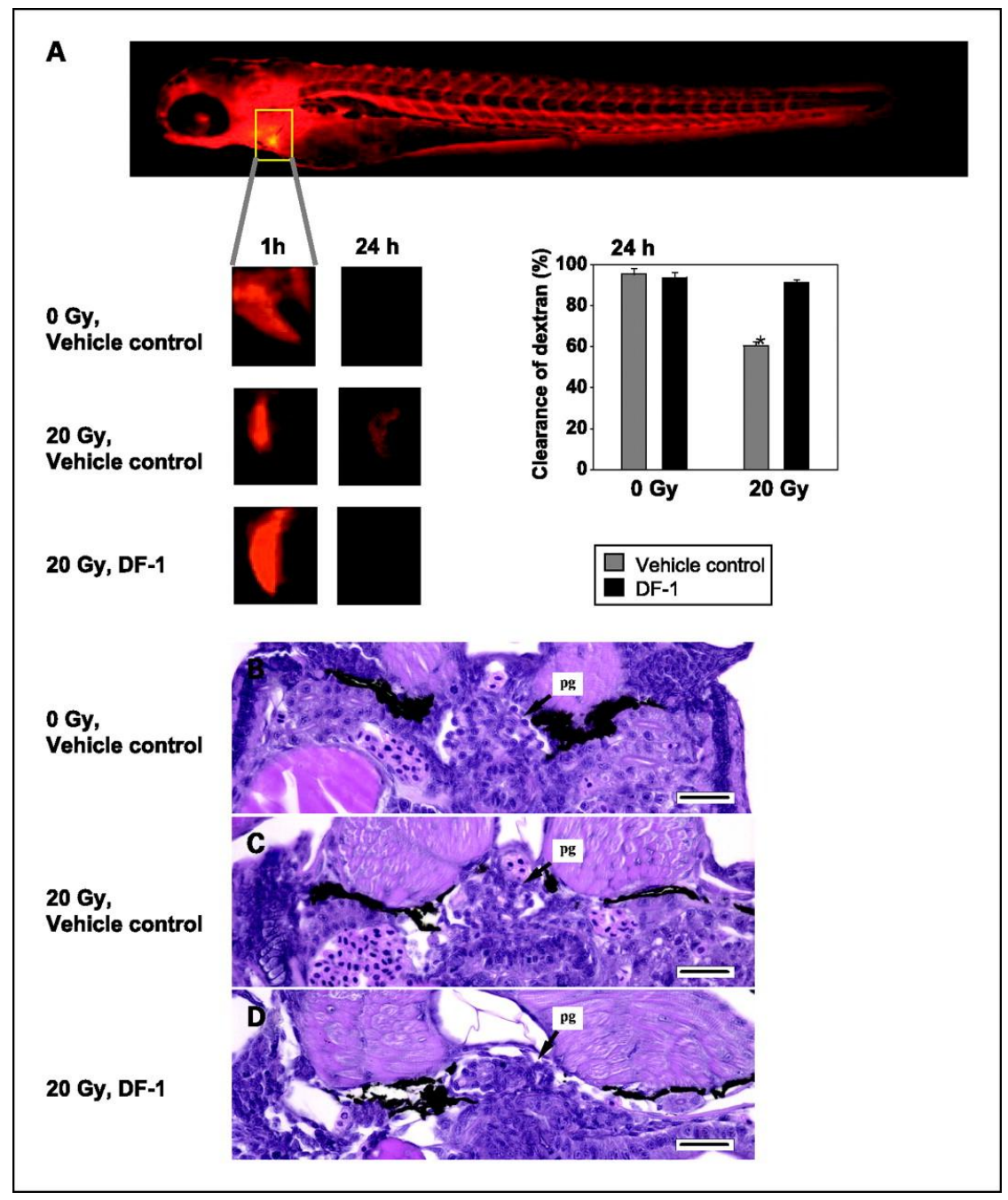

Figure 4 DF-1 attenuates radiation-associated reduction in dextran clearance. $A$, Representative photomicrographs illustrating clearance of tetramethylrhodamine-labeled $10 \mathrm{kDa}$ dextran after $24 \mathrm{~h}$ after cardiac injection in irradiated and control fish embryos. Radiation $(20 \mathrm{~Gy})$ led to delayed clearance measured at $24 \mathrm{~h}$. The bar graph shows the quantitative representation of results obtained by using the NIH Image $J$ software. Reduction of dextran clearance by radiation exposure $(20 \mathrm{~Gy})$ was significant $(\mathrm{p}=\mathbf{0 . 0 2 9})$ and abrogated by DF-1 $(100 \mu \mathrm{M})$ administered 3 hours prior to IR. $B$, IR was associated with renal glomerular changes that are not mitigated by DF-1. $C$, Pronephric glomerulus from embryo exposed to 20 Gy ionizing radiation at $4 \mathrm{dpf}$ is relatively smaller than control and the glomerular tuft is less cellular. $D$, treatment with DF-1 does not lessen IR-associated changes in pronephric glomerulus in embryo exposed to 20 Gy at 24 hpf.

Thus, DF-1 appears to restore compromised excretory function in irradiated zebrafish embryos. To determine whether this effect was due to protection of renal tissue against radiation effects, we assessed the effects of different treatments on renal tissue architecture. Compared with unirradiated control fish, embryos exposed to $20 \mathrm{~Gy}$ ionizing radiation exhibited minimal to moderate apoptotic-type individual cell death involving a variety of tissues; however, in the 
kidney, 20 Gy ionizing radiation exposure was associated with only a subtle but consistent decrease in the size and overall cellularity of pronephric glomeruli compared with controls (Fig. 4B and C). This particular morphologic effect did not appear to be mitigated by DF-1 treatment (Fig. $4 \mathrm{D}$ ). We, thus, tested whether the profound edema in zebrafish embryos following ionizing radiation exposure was secondary to reduced cardiac function [33]. Time-lapse microscopy of cardiac contractility in control and irradiated fish embryos revealed only marginal effects of 20 Gy ionizing radiation on heart rate and blood flow. These experiments show that radiation reduces clearance of dextran in zebrafish embryos, although it is presently unclear which cells or tissues are responsible for this effect.

\subsubsection{Reduction of ROS in irradiated zebrafish embryos treated with DF-1}

C-60 fullerenes are known to have antioxidant effects in vitro [9]. To investigate whether DF-1 exhibits similar effects in vivo, levels of ROS were determined in developing zebrafish embryos after ionizing radiation. Measurement of ROS in zebrafish revealed that free radicals following radiation exposure (20 Gy) were significantly diminished by DF-1 pretreatment (100 $\mu \mathrm{mol} / \mathrm{L})$ and indistinguishable from nonirradiated controls (Fig. 5). This result reveals ROS scavenging activity of DF-1 in vivo and suggests a putative mechanism for the observed radioprotective action of this fullerene in zebrafish. Note that similar studies cannot be done with amifostine due to molecular interactions between amifostine and the fluorescent dye, which lead to falsepositive values in the assay used. 


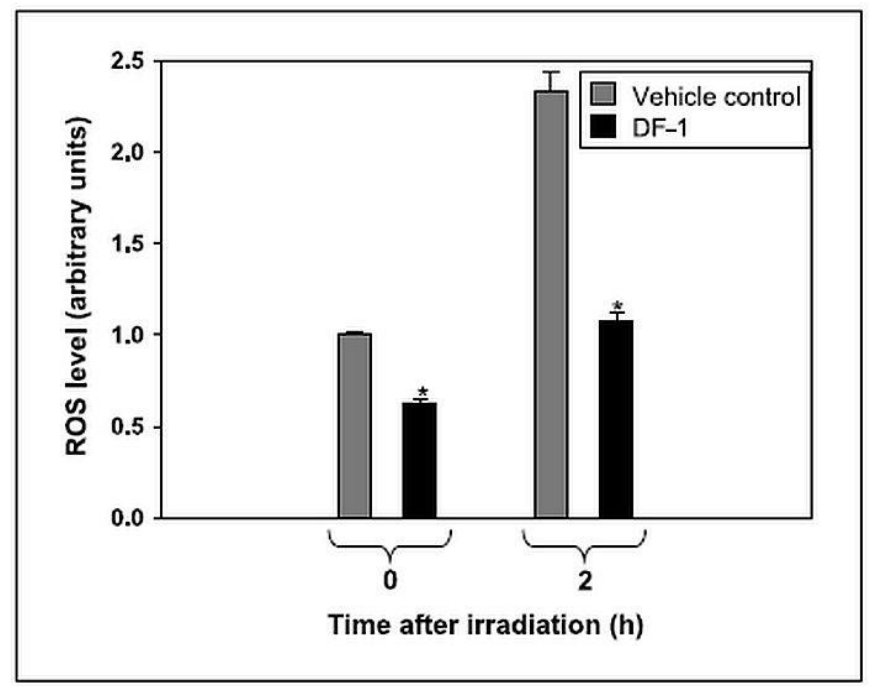

Figure 5 DF-1 decreases levels of ROS in irradiated fish embryos. Embryos were exposed to ionizing radiation at $24 \mathrm{hpf}$ in the absence or presence of DF-1 (100 $\mu \mathrm{mol} / \mathrm{L})$ given 3 hours before radiation.

\subsection{MnSOD mimetics}

M40403 and MnTE-2-PyP5+ had no apparent adverse effect on normal zebrafish development or viability even at ten times the effective dose. IR caused time- and dose-dependent perturbations of normal morphology and reduced survival of the exposed embryos. Administration of M40403 $(100 \mu \mathrm{M})$ or MnTE-2-PyP5+ $(2.5 \mu \mathrm{M})$ markedly attenuated radiation-induced time- and radiation dose-dependent morphological alterations and increased overall survival $(86.7 \% \pm 5.8$, $88.9 \% \pm 7.7$, respectively) relative to untreated but irradiated controls $(55.6 \% \pm 10.2)$. The positive control Amifostine treated embryos had an $86.5 \% \pm 8.3$ survival.

\subsection{Direct inhibitors of NF-KB and proteasome inhibitors}

\subsubsection{Proteasome inhibitors radiosensitize zebrafish embryos}

The proteasome inhibitor PS-341 (Bortezomib/VELCADE) with well-characterized inhibitory effects on NF- $\mathrm{BB}$ [23] has been approved for clinical use. PS-341 is a small, cell-permeable molecule inhibiting proteasome activity in a reversible manner. In addition to reducing the activation state of $\mathrm{NF}-\kappa \mathrm{B}$ by inhibiting the proteasomal degradation of $\mathrm{I} \kappa \mathrm{B}$, PS-341 affects 
several other molecular pathways and targets, leading to high expression levels of several proapoptotic proteins in certain experimental conditions [34]. In vitro, PS-341 has been found to enhance anti-tumor cell effects of certain chemotherapeutic agents [11, 35], ionizing radiation [36] and tumor cell targeting antibodies [37]. Yet, little is known about the combined effects of PS-341 and IR on normal cells and tissues of vertebrate organisms. To address this issue, PS-341 was used in zebrafish embryos exposed to high doses of ionizing radiation [24, 38]. First, a toxicity analysis was carried out with PS-341 alone (dose range, 0-10 $\mu \mathrm{mol} / \mathrm{L}$ ). No toxicity was noted in the aforementioned concentration range during the first 7 days after fertilization (Fig. 6).

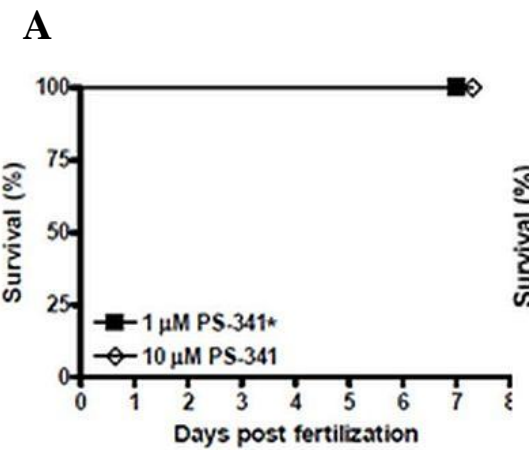

B

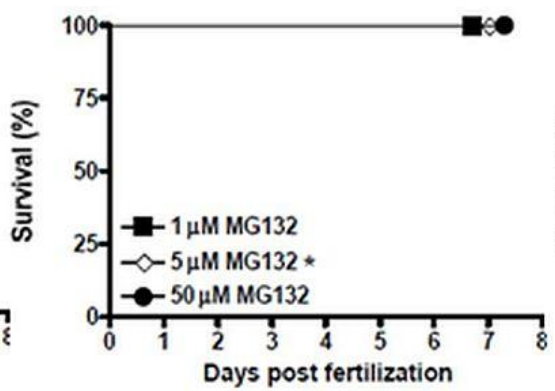

C

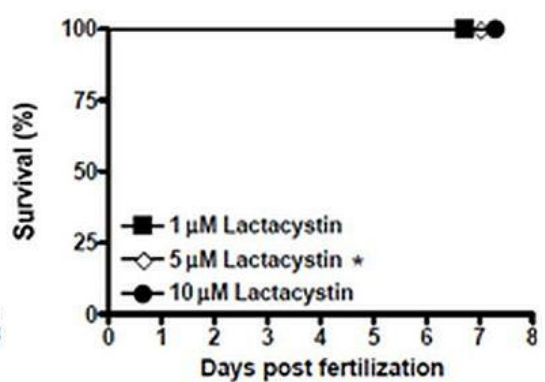

Figure 6 Toxicity analyses for PS-341 $(\leq 10 \mu \mathrm{M})$, MG132 $(\leq 50 \mu \mathrm{M})$ and Lactacystin $(\leq 10 \mu \mathrm{M})$. Each of the compounds was added to EM at $24 \mathrm{hpf}$ for 6 days and survival was scored at $7 \mathrm{dpf}$. Asterices indicate the doses used in our experiments.

In contrast, PS-341 ( $1 \mu \mathrm{mol} / \mathrm{L})$ markedly sensitized zebrafish embryos when administered 1 hour prior to radiation (Fig. 7). 


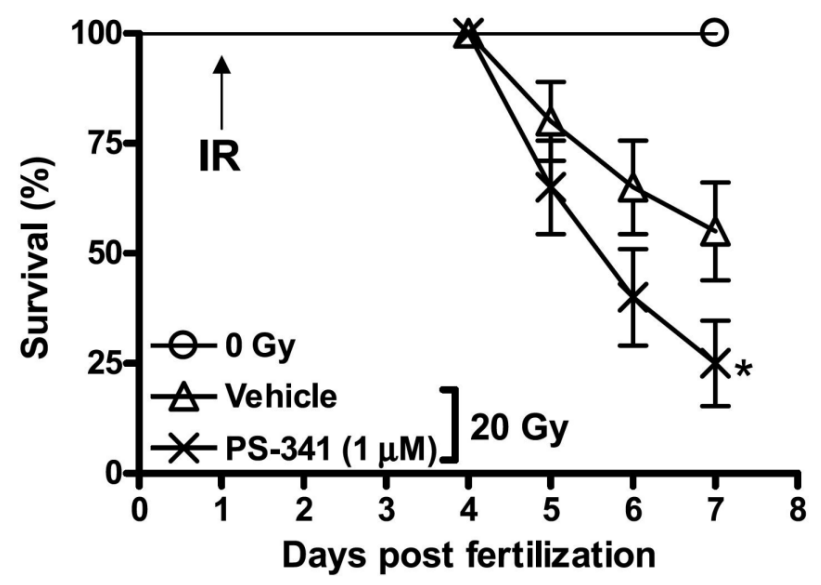

Figure 7 Effects of the proteasome inhibitor PS-341 on the radiation sensitivity of zebrafish embryos. Embryos were irradiated at $24 \mathrm{hpf}$ and survival was scored every day up to $7 \mathrm{dpf}$.

In HeLa cells, at the same concentration ( $1 \mu \mathrm{mol} / \mathrm{L})$ PS-341 abrogated the TNF- $\alpha$-induced NF$\kappa \mathrm{B}$ activity, whereas it did not significantly affect the basal activity (Fig. 8).

A

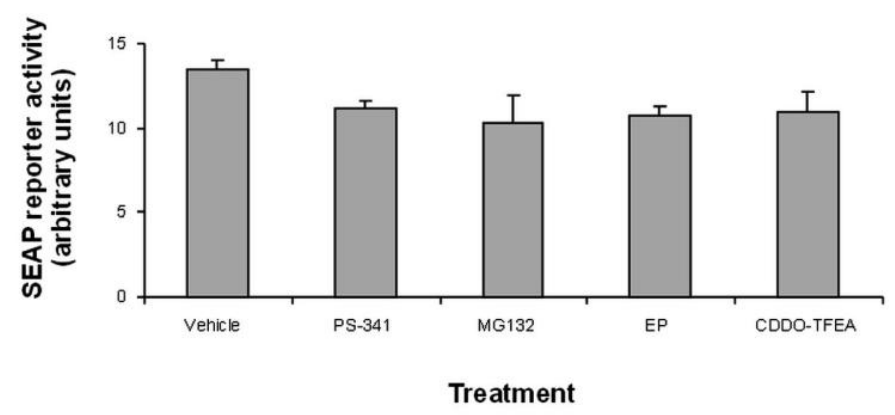

B

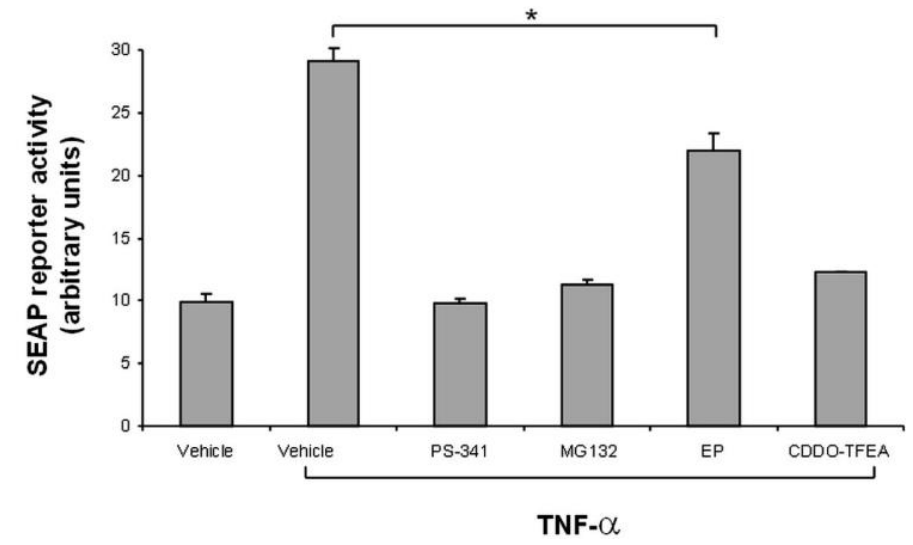

Figure 8 Targets and effects of pharmacologic agents on NF-кB activity in vitro. A, Effects of the proteasome inhibitors PS-341 and MG132 as well as EP and CDDO-TFEA on baseline NF- $\kappa B$ activity in HeLa cells. $B$, Effects of compounds on TNF- $\alpha$-induced NF- $\kappa B$ activity in HeLa cells. 
To ascertain whether radiation sensitization by PS-341 could be reproduced using other inhibitors of the proteasome, we next tested the effects of MG132, a non-boronated small molecule inhibitor of the 26S proteasome [39], on zebrafish survival in the presence and absence of ionizing radiation. Similar to PS-341, MG132 was nontoxic when applied as a single agent to zebrafish embryos (dose range, $0-50 \mu \mathrm{mol} / \mathrm{L}$ ), yet efficiently inhibited TNF- $\alpha$-induced but not the baseline NF- $\kappa \mathrm{B}$ activity in HeLa cells when used at $5 \mu \mathrm{mol} / \mathrm{L}$ (Fig. 8). At this concentration, however, MG132 marginally sensitized zebrafish embryos to the lethal effects of 20 Gy ionizing radiation albeit to a lesser degree than PS-341 (Fig. 9). An irreversible proteasome inhibitor (lactacystin) at a nontoxic concentration $(5 \mu \mathrm{mol} / \mathrm{L})$ also slightly radiosensitized zebrafish embryos in a manner similar to MG132 (Fig. 10).

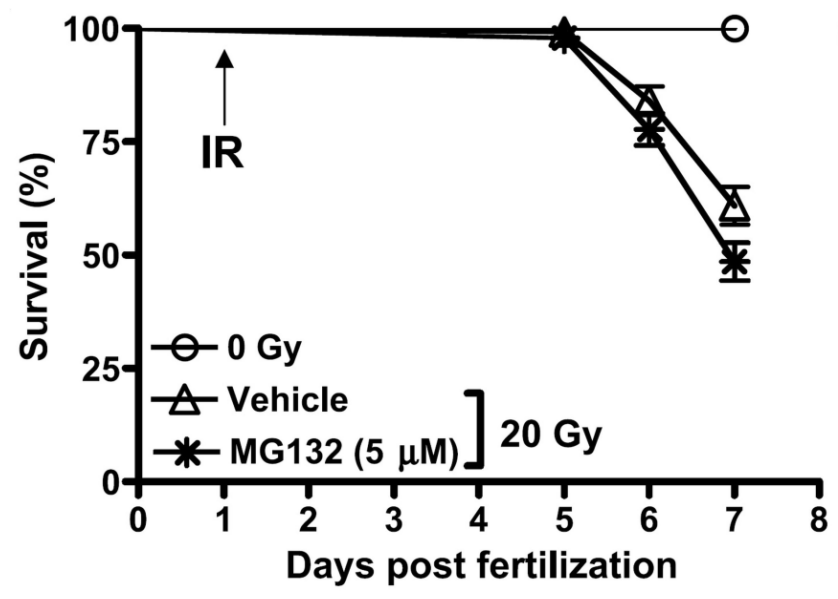

Figure 9 Effects of the proteasome inhibitor MG-132 on the radiation sensitivity of zebrafish embryos. Embryos were irradiated at $24 \mathrm{hpf}$. 


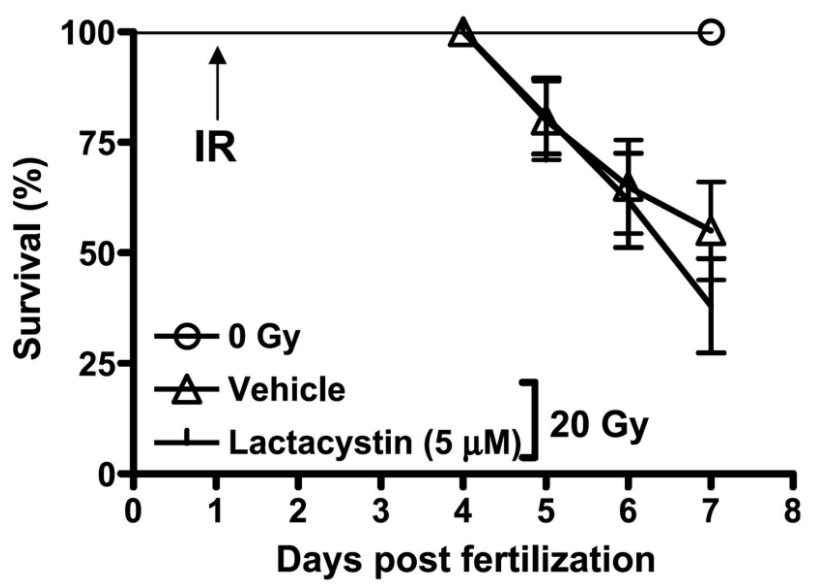

Figure 10 Effects of the proteasome inhibitor lactacystin on the radiation sensitivity of zebrafish embryos. Embryos were irradiated at $24 \mathrm{hpf}$.

These results show that several proteasome inhibitors do not protect normal cells and tissues in the developing zebrafish embryos against the deleterious effects of IR. Since p53 is a main target of proteasome degradation and enhances IR-associated tissue damage in mice [40-42] and zebrafish [43, 44] we asked whether the deleterious effects of proteasome inhibitors could be linked to p53 stabilization and subsequent induction of target genes.

Consistent with our previous observations, ablating p53 expression by antisense morpholino oligodeoxynucleotide [45] or p53 function by PTF- $\alpha(1 \mu \mathrm{mol} / \mathrm{L})$ administered at $24 \mathrm{hpf}$ [44] markedly improved zebrafish survival following IR either alone or in combination with PS-341. However, reverse transcription-PCR analysis did not reveal increased steady-state mRNA levels of the p53 targets $p 21 / W A F 1, b a x$, or the zebrafish ortholog of $m d m 2$ in PS-341-treated embryos whereas ionizing radiation led, as expected, to elevated transcript levels for these genes (Fig. 11). 


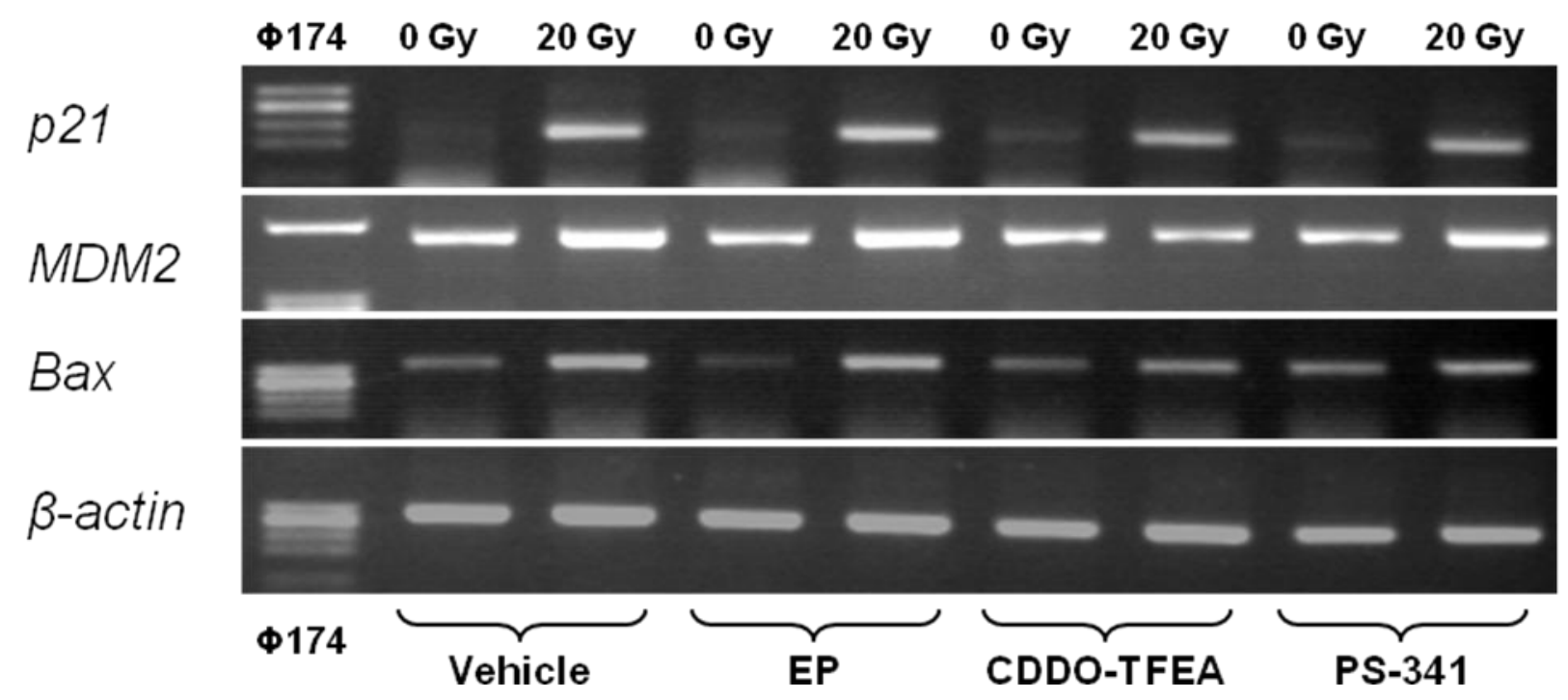

Figure 11 Effects of IR and PS-341 on steady-state transcript levels of the p53 target genes p21/Waf1, $m d m 2$ and bax as determined by semiquantitative PCR standardized to $\beta$-actin. The effects of EP and CDDO-TFEA on target gene expression are shown for comparison.

Thus, the molecular target(s) responsible for the radiation sensitizing effects by PS-341 and their relationship to the p53 response remain to be identified.

\subsubsection{Radiation protection of zebrafish embryos by the NF-кBp65 inhibitor ethyl pyruvate}

In consideration of the fact that proteasome inhibitors affect multiple intracellular pathways in addition to NF- $\kappa \mathrm{B}$ and to pinpoint the functional contribution of NF- $\kappa \mathrm{B}$ to the radiation response of zebrafish embryos, we tested the effects of a series of pharmacologic inhibitors of NF- $\mathrm{B}$ activity with different mechanisms of action on the radiation response of zebrafish embryos. Reducing NF- $\kappa \mathrm{B}$ activity by expression of upstream regulator $\mathrm{I} \kappa \mathrm{B}$ has been shown to cause several embryonic malformations in zebrafish embryos [46, 47] and, therefore, was not further considered. In addition, knock-down of the NF- $\mathrm{B}$ p65 subunit by antisense morpholinos similarly caused severe morphologic defects, the "no tail phenotype", during the first 3 days of development (Fig. 12), consistent with previously published findings [47] and was not informative in the context of assaying the radiation response. 
A

Vehicle

NF-KB p65 MO
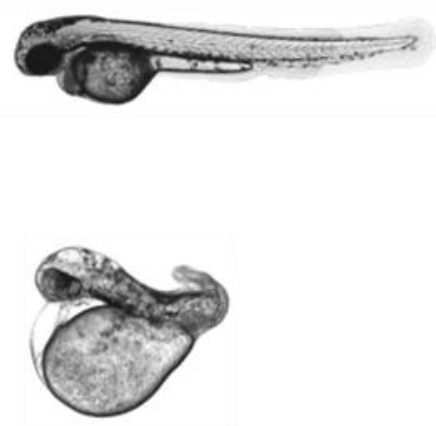

B

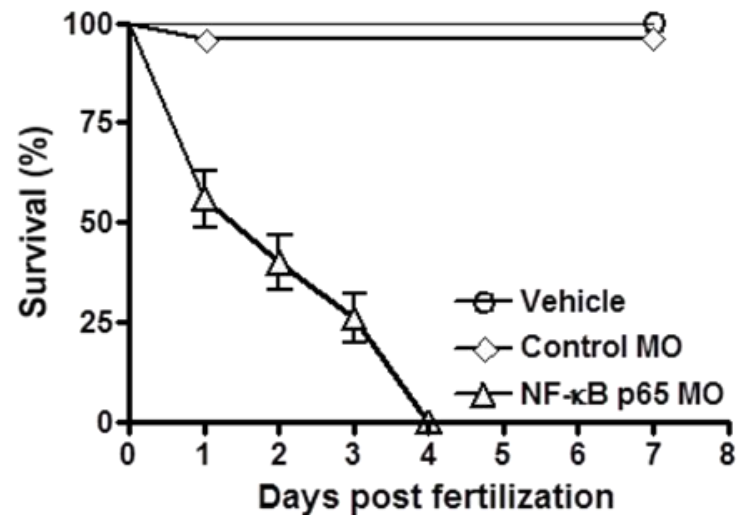

Figure 12 Lethal effect of morpholino-mediated NF-kB knockdown on zebrafish embryos. $A$, Morphology of NF-kB-MO-treated embryos. B, Time-dependent survival of control, control-MO (random control morpholino, Gene Tools) and NF-kB-MO-treated embryos.

Instead, we used pharmacologic inhibitors that disrupt the canonical pathway to NF- $\mathrm{B}$ activation and could be used at concentrations that do not interfere with embryonal development. First, we tested EP, a ROS scavenger and inhibitor of NF- $\kappa B p 65$ [48]. EP inhibits the DNA

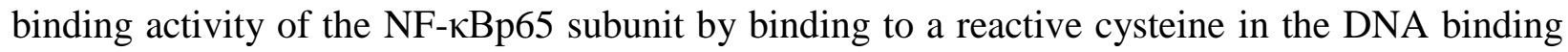
site (Cys 38) of NF- $\kappa$ Bp65 [18], which is shared between humans and zebrafish (as shown below).

\section{NF-kB p65}

...RGMRFRYKCEGRSAGSIPGE... ...RGMRFRYKCEGRSAGSIPGE...

\section{human} zebrafish

EP has been shown to mitigate deleterious effects of whole-body irradiation in mice [17]. We observed that EP similarly not only protected against but also mitigated lethality associated with total body irradiation of zebrafish embryos (Fig. 13). 

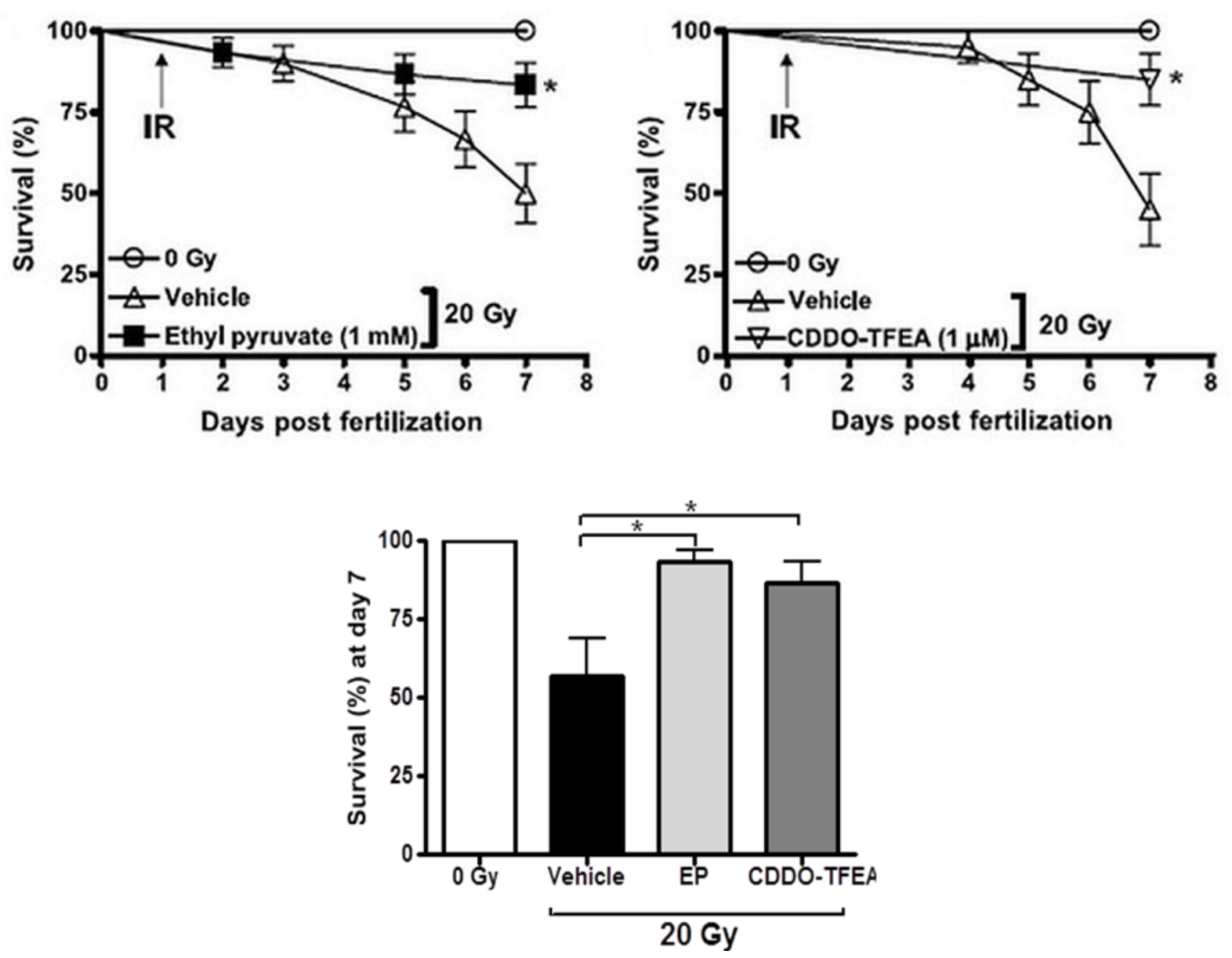

Figure 13 Protection against lethal effects of radiation ( $20 \mathrm{~Gy}$ ) by direct NF-kB inhibitors (top panels). Survival benefit of zebrafish embryos treated with either EP $(1 \mathrm{mmol} / \mathrm{L})$ or CDDO-TFEA $(1 \mu \mathrm{mol} / \mathrm{L}) 2$ hours post radiation at $24 \mathrm{hpf}$ (bottom panel).

EP was administered at various time points ranging from 1 hour prior to radiation exposure to 3 hours post-irradiation. The ROS scavengers amifostine and DF-1 were used as positive controls in these experiments as we observed marked protection of embryos by these two compounds in earlier work [24, 49]. Whereas amifostine and DF-1 afforded protection against the deleterious effects of ionizing radiation when administered prior to or concurrent with radiation, neither compound could mitigate the lethal effects of radiation when given beyond 15 minutes after ionizing radiation (Fig 2) [49]. In marked contrast, EP administered up to 2 hours after radiation significantly reduced ionizing radiation-associated lethality (Fig 13). 


\subsubsection{The IKK inhibitor CDDO-TFEA mitigates radiation effects in zebrafish embryos}

To further address the relevance of NF- $\mathrm{KB}$ activation in modulating radiation sensitivity of zebrafish embryos, we used CDDO-TFEA that inhibits NF- $\kappa B$ signaling by interacting with Cys179 of IKK $\beta$, inhibiting its activity and preventing phosphorylation and proteasomal degradation of IкB [50] and, thus, through a molecular mechanism distinct from EP. The amino acid sequence around this reactive Cys179 is also highly conserved in zebrafish (see below).

\section{$\underline{\underline{I K K} \beta}$}

\section{...HKIIDLGYAKELDQGSLCTSFVGTL... human ...HKIIDLGYAKELDQSSLCTSFVGTL... $\quad$ zebrafish}

CDDO-TFEA not only protected against but also mitigated overall lethal effects of radiation in zebrafish embryos in a manner similar to EP (Fig. 13).

We next determined whether mitigation of radiation effects co-segregated with the capacity of the compounds under investigation to act as ROS scavengers. This was based on the findings that, in addition to directly binding to IKK $\beta$, CDDO has been reported to induce expression of enzymes catalyzing antioxidant reactions in peripheral blood mononuclear cells due to increased nuclear accumulation of $\mathrm{Nrf} 2$, an oxidant-responsive bZIP transcription factor [51, 52]. Whereas EP was an effective ROS scavenger in irradiated zebrafish embryos, CDDO-TFEA - at least at the concentration tested - did not reduce ROS levels measured 2 hours after radiation (Fig. 14). 


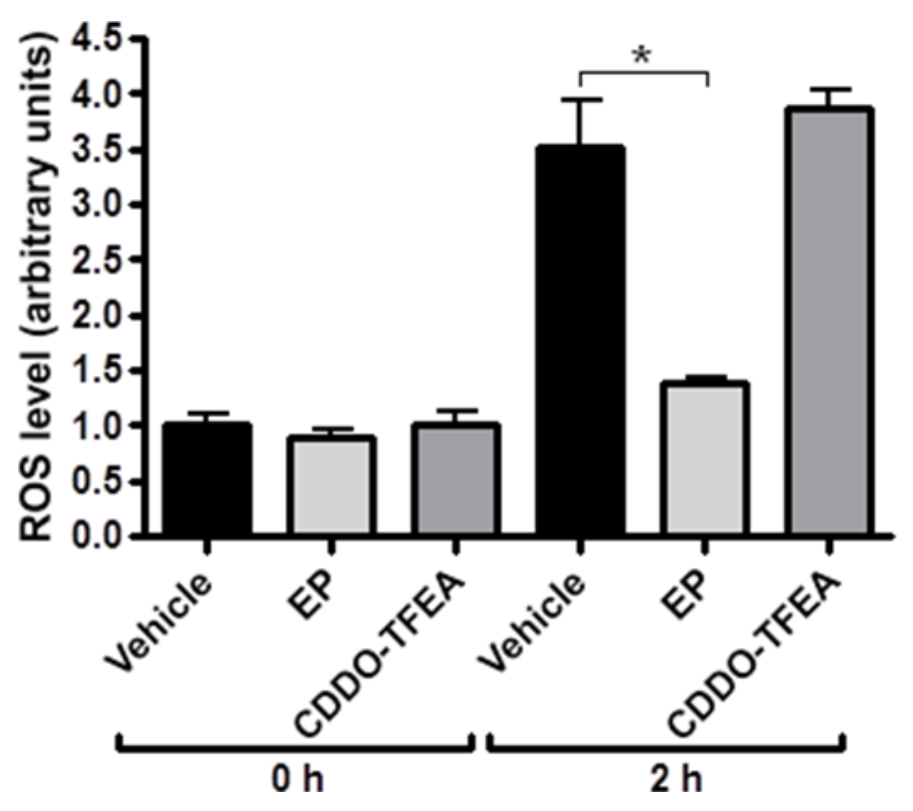

Figure 14 EP but not CDDO-TFEA is an effective ROS scavenger in irradiated zebrafish embryos. Zebrafish embryos were exposed to IR (20 Gy) at $24 \mathrm{hpf}$ and ROS levels determined at $26 \mathrm{hpf}$, i.e., $2 \mathrm{~h}$ after IR as described in Materials and Methods.

Thus, at least the effect of CDDO-TFEA at $1 \mu \mathrm{M}$ on radiation mitigation cannot be attributed to ROS scavenging, whereas in the case of EP, ROS scavenging and NF- $\kappa$ B inhibition may be jointly responsible for the beneficial effects of EP in the mitigation setting. The ROS scavengers with no known effect on NF- $\mathrm{B}$ signal transduction (amifostine and DF-1) do not mitigate radiation effects if administered beyond 15 minutes after ionizing radiation. To further assess whether IKK inhibition can afford radioprotection, the following small molecule IKK inhibitors were tested: Wedelolactone (IKK inhibitor 2), BMS-345541 (IKK inhibitor 3) and IKK-2 inhibitors 4 and 5. All four agents protected zebrafish embryos against the deleterious effects of radiation in a manner similar to CDDO-TFEA and EP (Fig. 15). 


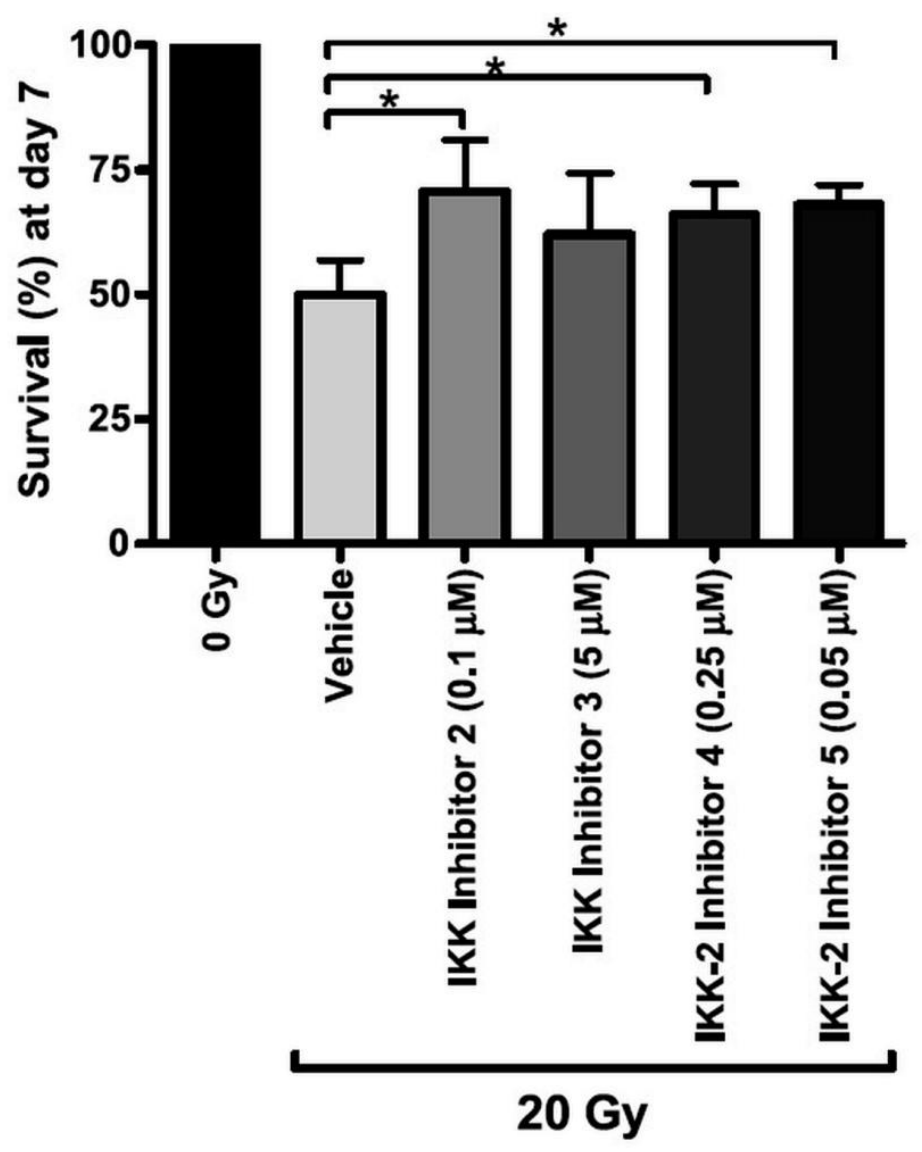

Figure 15 Radiation protection of zebrafish embryos exposed to $20 \mathrm{~Gy}$ and treated for $1 \mathrm{~h}$ prior to irradiation with different IKK inhibitors.

Moreover, these IKK inhibitors are not known to have antioxidant properties and primarily inhibit IKB $\alpha$ phosphorylation by IKK $\beta$. These results suggest that prolonged and excessive activation of the canonical NF-KB pathway is a major contributor to radiation toxicity in the developing vertebrate organism and that inhibiting this pathway may protect the organism against the deleterious effects of radiation.

\subsubsection{Organ-specific radiation protection by CDDO-TFEA and EP}

Having established that EP and CDDO-TFEA provide whole-body protection against lethal doses of radiation and in consideration of the fact that these compounds are in preclinical development, we next determined organ-specific radiation protective effects of these two NF- $\kappa B$ inhibitors. As expected, consistent with earlier reports, unirradiated controls showed minimal AO positivity, in contrast, embryos exposed to 20 Gy displayed distinct AO positivity in the central 
nervous system and along the body axis of irradiated embryos [43]. Both NF- $\kappa \mathrm{B}$ inhibitors markedly reduced radiation-induced acridine orange staining (Fig. 16).
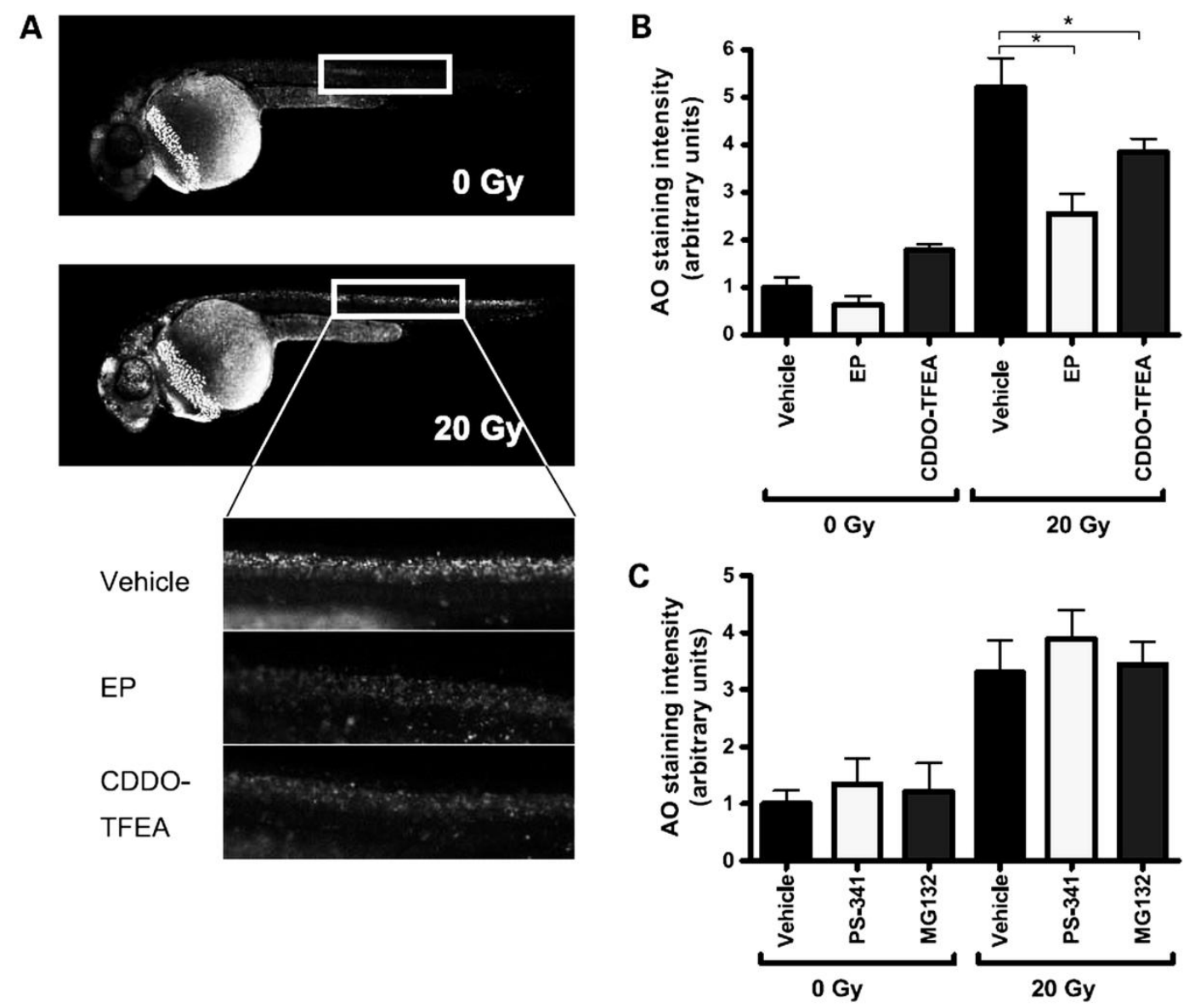

Figure 16 Reduction of organism-wide apoptosis by EP and CDDO-TFEA treatment pre- and postradiation. Acridine orange (AO) staining of whole embryos was performed 6 hours post radiation at 30 hpf. $A$, Representative examples of control and irradiated fish revealing strong AO staining in the central nervous system and along the body axis induced by radiation $(20 \mathrm{~Gy})$. Regions selected for quantitative evaluation are boxed. $B$, Reduced AO staining in CDDO-TFEA and EP-treated embryos exposed to IR. $C$, PS-341 or MG132 treatment does not significantly affect AO staining of embryos exposed to IR.

Ionizing radiation compromised zebrafish kidney function as determined by delayed excretion of a fluorescent dextran injected intracardially.

Pre-treatment with EP but not CDDO-TFEA significantly reversed the effect of ionizing radiation on dextran clearance of irradiated embryos to near normal levels (Fig. 17), suggesting protection against radiation-induced renal toxicity. 
A

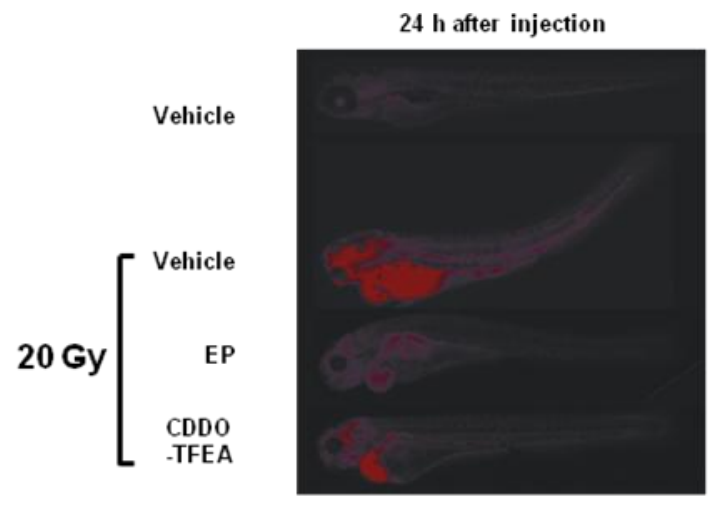

B

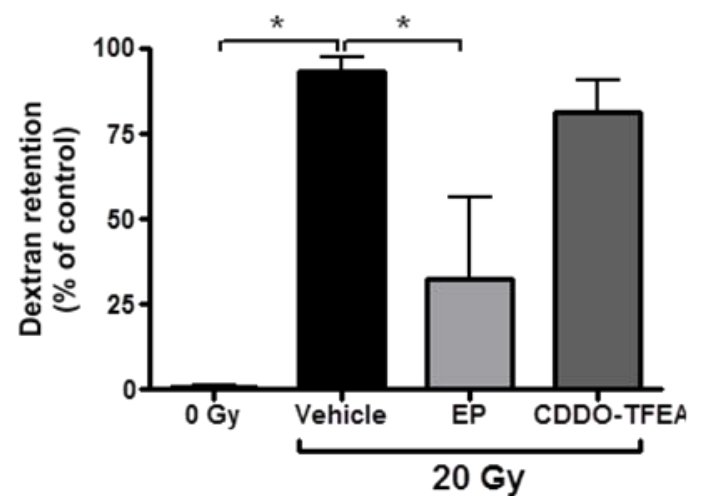

Figure 17 Clearance of tetramethylrhodamine-labeled 10-kDa dextran was reduced after ionizing radiation $(20 \mathrm{~Gy})$ in relative to EP pretreated zebrafish exposed to ionizing radiation. In an unirradiated fish, dextran is rapidly cleared from the cardiac area. Effects of EP and CDDO-TFEA on radiation-induced kidney damage as determined by dextran clearance. $A$, Representative images of dextran retention in irradiated embryos and effects of EP and CDDO-TFEA on this phenomenon. B, Quantitative representation of dextran retention in embryos treated with either EP or CDDO-TFEA as indicated; results are expressed relative to vehicle-treated, non-irradiated controls. Asterices denote statistically significant differences between the experimental groups indicated by brackets.

It is unknown whether this effect reflects differences in ROS scavenging capacity between the two compounds (Fig. 14) or is due to differences in pharmacokinetics or pharmacodynamics. In addition, radiation of zebrafish embryos is associated with a high incidence of the "curly-up" phenotype. Both CDDO-TFEA and EP reduced the incidence of curly-up significantly (Fig. 18).
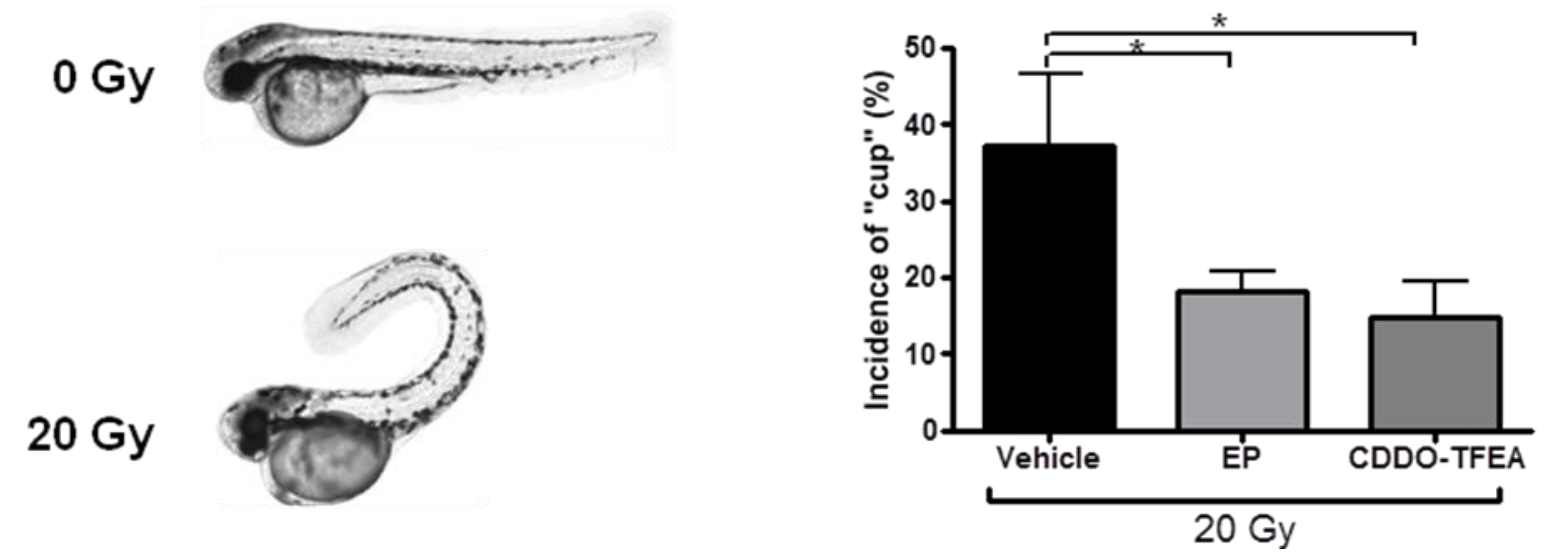

Figure 18 Pretreatment with either EP or CDDO-TFEA reduces the incidence of mid-line development. 
Finally, we determined the effects of radiation on the developing gastrointestinal system. This was done in consideration of several prior reports suggesting that NF- $\kappa \mathrm{B}$ activation protects the gastrointestinal tract of higher vertebrates against acute radiation damage [53] [54]. Radiation protection of the gastrointestinal system was determined in several ways.

First, we assayed overall gastrointestinal function by scoring "long-term" survival of fish irradiated in the presence and absence of EP or CDDO-TFEA (up to $15 \mathrm{dpf}$ ). Fish larvae become dependent on external food sources at approximately $6 \mathrm{dpf}$ when the contents of the yolk sac are depleted. Significant functional damage to the gastrointestinal system will thus lead to death by starvation within 10 days after conception [28]. Conversely, survival of zebrafish beyond two weeks indicates a functionally adequate gastrointestinal tract. Both EP and CDDO-TFEA prolonged survival of zebrafish larvae (Fig. 19) although this effect was statistically significant only in the case of CDDO-TFEA.

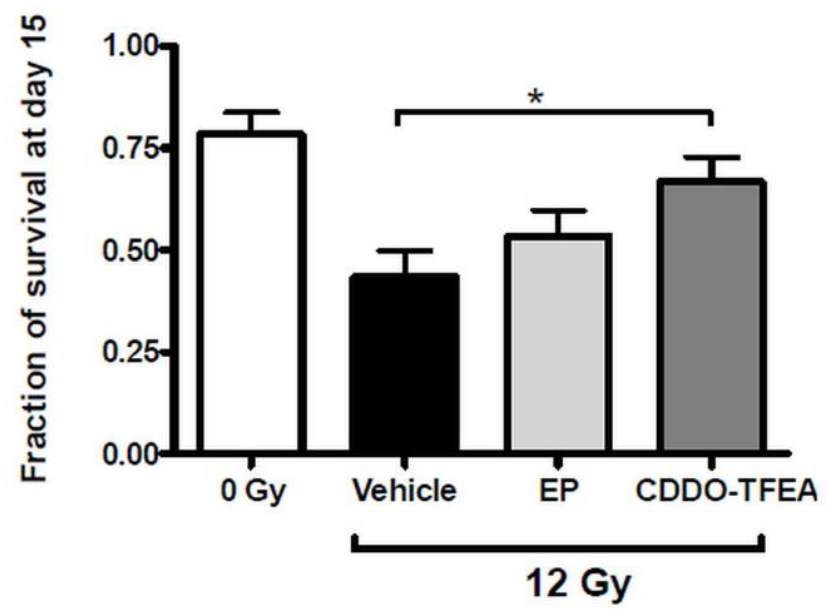

Figure 19 "Long-term" survival of fish irradiated in the presence and absence of EP or CDDO-TFEA. Extended survival of irradiated zebrafish embryos pretreated with EP and CDDO-TFEA as determined at 15 dpf.

To address the combined effects of radiation and EP or CDDO-TFEA treatment on the developing gastrointestinal system further, we determined gastrointestinal lumen formation by use of the fluorescent reporter PED6 [29] that is metabolized and excreted through the gastrointestinal system. This analysis revealed severely impaired lumen formation of the gastrointestinal system induced by ionizing radiation (15 Gy) and partial restoration of lumen 
formation and fluorescent dye excretion by treatment with either EP or CDDO-TFEA. These functional results were complemented by examining the histologic appearance of the gastrointestinal system 5 days after radiation exposure in the presence and absence of the NF- $\mathrm{KB}$ inhibitors under investigation (Fig. 20).

A
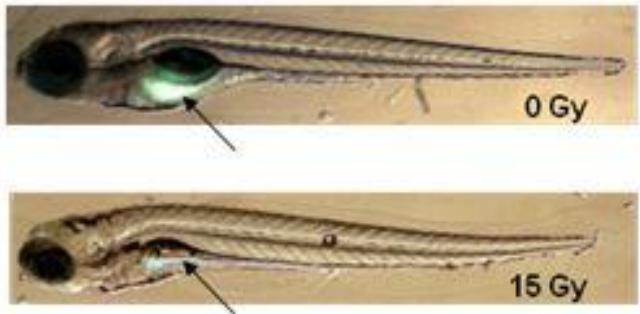

B

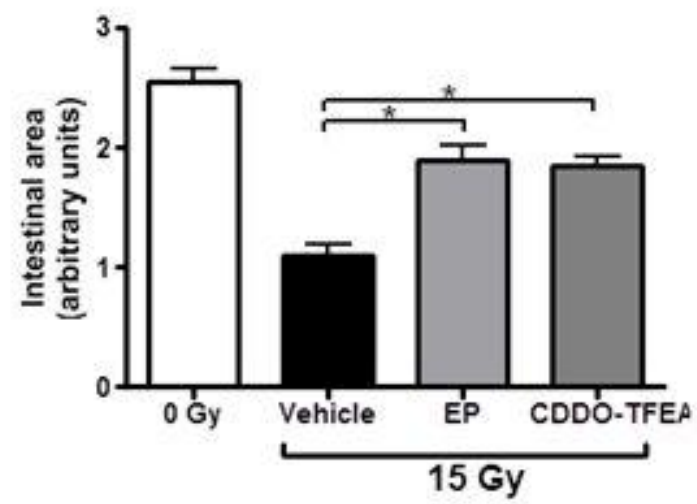

C

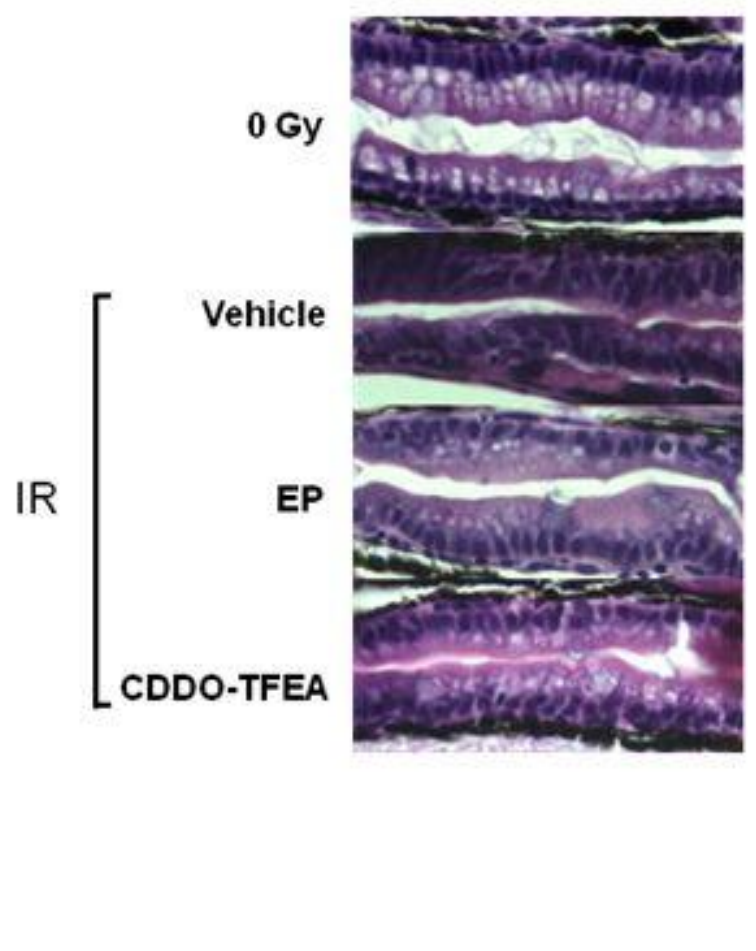

Figure 20 Effects of EP and CDDO-TFEA on radiation-induced alterations of the gastrointestinal system. $A$, Improved PLA $\mathrm{A}_{2}$ activity and gastrointestinal lumen formation in irradiated zebrafish treated with either EP or CDDO-TFEA. Dequenched fluorescence reflects endogenous PLA $A_{2}$ activity and transport of cleavage products through the lumen of the developing gastrointestinal system. B, Quantitative evaluation of gastrointestinal lumen formation as determined by fluorescent dye content at 6 dpf. $C$, Representative histological sections of hindgut proximal to the cloaca at $6 \mathrm{dpf}$ ( 5 days post radiation (12 Gy).

The hindgut mucosal epithelium immediately proximal to the cloaca revealed distinct cellular changes associated with sublethal ionizing radiation exposure, including irregular shape and disorganization of the columnar absorbing cells with redistribution of nuclei away from the basal orientation. In addition, decreased goblet cell numbers were observed. By contrast, EP and CDDO-TFEA pretreatment of irradiated embryos restored, in part, the columnar structure of absorbing cells and basal location of nuclei. 


\section{DISCUSSION}

\subsection{DF-1}

The experiments with DF-1 illustrated that, as expected for an agent with antioxidant properties, DF-1 protected against and, at least to a limited extent, mitigated radiation-induced lethality in zebrafish embryos.

The unmodified Buckminster fullerene C60 reportedly exerts toxic effect in vitro and in several in vivo systems including the aquatic largemouth bass [55]. This toxicity has been attributed, in part, to lipid peroxidation by $\mathrm{C} 60$. In contrast to unmodified $\mathrm{C} 60, \mathrm{DF}-1$ has been structurally altered to increase water solubility and, thereby potentially reduce C60-associated toxicity.

The modified fullerene DF-1 provides radioprotection to several target tissues and organs and acts as an oxygen radical scavenger in this in vivo model system.

\subsection{Manganese superoxide dismutase mimetics}

The degree of radioprotection provided by the SOD mimetics M40403 and MnTE-2-PyP5+ was comparable to that provided by Amifostine, but they proved to be effective at much lower concentrations, especially MnTE-2-PyP5+. Our finding is consistent with another report demonstrating the survival benefit of M40403 in mice exposed to lethal whole-body irradiation [56]. MnTE-2-PyP5+ was also reported to selectively protect normal cells but not tumor cells [57] against radiation-induced damage.

\subsection{Direct inhibitors of NF- $\mathrm{B}$ and proteasome inhibitors}

Our results show that 6 of 6 pharmacologic inhibitors with different chemical structures and mode of actions inhibited the canonical pathway of NF- $\mathrm{B}$ activation (consisting of $\mathrm{IKK} \beta / \mathrm{I} \kappa \mathrm{B} / \mathrm{NF}-\kappa \mathrm{Bp} 65)$ and provided protection against radiation-induced overall lethality and damage to multiple organ systems of the developing zebrafish. By contrast, 3 of 3 proteasome inhibitors did not afford radiation protection, but made zebrafish embryos more sensitive to the lethal effects of ionizing radiation. Taking into account that each of the pharmacologic agents 
tested in this study is likely to affect targets other than NF- $\kappa \mathrm{B}$, it is remarkable that radioprotection co-segregated with interference with activation of the canonical pathway to NF$\kappa \mathrm{B}$. This observation suggests that NF- $\mathrm{B}$ may be the relevant target for radiation protection by pharmacologic IKK/NF- $\mathrm{B}$ inhibition.

Currently, there is no consensus about the functional contribution of NF- $\kappa \mathrm{B}$ activation to the radiation response [58]. Numerous reports of radiosensitization of tumor cells in vitro and in vivo by NF- $\kappa \mathrm{B}$ inhibition are contrasted by relatively few such reports dealing with normal cells. The use of genetically engineered mouse models to monitor $\mathrm{NF}-\kappa \mathrm{B}$ dysfunction in normal tissues has been limited due to embryonic lethality observed in IKK $\beta$ [59] and NF- $\kappa B p 65$ [60] knockout animals. In cases where either conditional knockouts were made or transgenic mice were generated by forced expression of dominant negative regulators to modulate $\mathrm{NF}-\kappa \mathrm{B}$ activation, the interpretation of results is further complicated by compensatory adjustments of homeostasis [61]. This study sidesteps the problems inherent to using genetic models by examining the effects of pharmacologic agents applied at concentrations that reduce but do not abrogate NF- $\mathrm{B}$ activity. Observation of overall effects of ionizing radiation on zebrafish survival as well as effects on specific target organs allowed us to monitor the effects of drug classes grouped according to target specificity and mechanisms of action. This approach had the advantage to minimize confounding effects due to unknown, off-target effects of any pharmacologic agent. As expected, ablating NF- $\kappa \mathrm{B}$ activity by targeting IKK $\beta$ or NF $\kappa \mathrm{Bp} 65$ expression using antisense approaches led to a dramatically different outcome as these interventions were associated with embryonic lethality even in the absence of genotoxic stress (Fig. 12). This result is consistent with the view that inhibition of excess NF- $\kappa \mathrm{B}$ activity following lethal irradiation is beneficial whereas blocking $\mathrm{NF}-\kappa \mathrm{B}$ expression and/or activation altogether, as in genetic knockout/knockdown models, is deleterious even in the absence of irradiation. This contention is also supported by our finding that EP and CDDO-TFEA at the nontoxic concentration used here disrupted TNF- $\alpha$-induced NF- $\kappa$ B activation but not the basal NF- $\kappa$ B activity in HeLa cells in vitro (Fig. 8). Importantly, CDDO-TFEA and EP not only protected against but also mitigated the lethal effects of radiation. This result is of interest as it points to the importance of sustained $\mathrm{NF}-\kappa \mathrm{B}$ activation consistent with inflammatory responses rather than the burst of NF- $\kappa \mathrm{B}$ activity observed immediately after radiation exposure. 
Interestingly, radiation protection of zebrafish embryos by NF- $\kappa \mathrm{B}$ inhibitors extended to the gastrointestinal system whereas previous work using genetically modified mice [53] and the TLR5 ligand flagellin [54] implicated NF- $\kappa B$ activation in radiation protection of gastrointestinal stem cells. The reason(s) for this difference are unclear at this point. However, the TLR5 ligand flagellin [54] exerts pleiotropic stimulatory effects on multiple signaling pathways that include $\mathrm{NF}-\kappa \mathrm{B}$ but also p38, Erk/mitogen-activated protein kinase, and potentially, signal transducers and activators of transcription [62]. It has not yet been reported which of these effects alone or in combination can result in radioprotection provided by flagellin [54].

In addition, the NF- $\kappa \mathrm{B}$ inhibitory effects of both EP and CDDO-TFEA are completely reversible, whereas genetic ablation is not, and this condition could affect the outcomes of NF- $\kappa \mathrm{B}$ activation in reference to gastrointestinal function. Our findings are further consistent with the view that excessive NF- $\kappa \mathrm{B}$ activation, as observed in the context of chronic inflammation, is potentially deleterious to the gastrointestinal system [63] and, thus, down-modulating NF- $\kappa B$ activity but not abolishing it altogether can be beneficial in certain settings [64]. Although the details of these diverse outcomes in different model systems remain to be sorted out, these results clearly show that reducing NF- $\mathrm{B}$ activity with a variety of compounds with different mechanisms of action diminishes radiation-induced damage to several organ systems in the developing zebrafish embryos.

In conclusion, the most salient finding of this study with $\mathrm{NF}-\kappa \mathrm{B}$ inhibitors is that direct inhibitors of NF- $\mathrm{NB}$ activity provided effective protection and mitigation against overall lethality and specific organ damage caused by ionizing radiation in zebrafish embryos. Direct NF- $\kappa \mathrm{B}$ inhibitors also exert antineoplastic effects in select model systems as shown extensively for CDDO-TFEA and derivatives thereof [65-71]. These findings are consistent with a favorable therapeutic window for NF- $\mathrm{B}$ inhibitors when used in combination with radiation and, potentially, chemotherapeutic drugs. 


\section{SUMMARY}

There is a great interest in developing radioprotectors to spare normal tissue during chemoand/or radiotherapy or nuclear accidents.

We used a relatively novel vertebrate organism, the zebrafish, as our experimental model system. This model has several advantages over conventional animal models: high fecundity, easy upkeep, large sample sizes, and high similarity to humans - the entire genome is sequenced. To achieve protection against ionizing radiation, we used different classes of drugs with distinct mechanisms of action. The radical oxygen scavenger DF-1 was tested first, which is a nanoparticle with a fullerene structure. Amifostine (the only radioprotector in clinical use) was used as a positive control. The chemically modified C60 compound proved effective affording protection of zebrafish embryos against a single dose of 20 Gy (which was previously defined as LD50) in all aspects of our study: morphology, overall survival, apoptosis as well as specific organ readouts including the kidney.

We used zebrafish embryos to assess the capacity of two different classes of pharmacologic agents known to target $\mathrm{NF}-\mathrm{\kappa B}$ to modify radiation toxicity in the vertebrate organism. These were direct inhibitors of NF- $\kappa \mathrm{B}$ activity; that is, ethyl pyruvate and the synthetic triterpenoid CDDO-TFEA, and proteasome inhibitors, including PS-341, MG132 and lactacystin. The proteasome inhibitors either did not significantly affect radiation sensitivity of zebrafish embryos (MG132, lactacystin) or rendered zebrafish embryos more sensitive to the lethal effects of ionizing radiation (PS-341). Radiosensitization by PS-341 was reduced in fish with impaired p53 expression or function but not associated with enhanced expression of select p53 target genes. In contrast, the direct NF- $\mathrm{BB}$ inhibitors EP and CDDO-TFEA significantly improved overall survival of lethally irradiated zebrafish embryos. In addition, direct NF- $\kappa \mathrm{B}$ inhibition reduced radiation-induced apoptosis in the central nervous system, abrogated aberrations in body axis development, restored metabolization and secretion of a reporter lipid through the gastrointestinal system, and improved renal clearance compromised by radiation. Unlike amifostine and DF-1, EP and CDDO-TFEA not only protected against but also mitigated radiation toxicity when administered 1 to 2 hours after ionizing radiation. Finally, four additional 
IкB kinase inhibitors with distinct mechanisms of action similarly improved overall survival of lethally irradiated zebrafish embryos. In conclusion, inhibitors of canonical pathways to NF-kB activation may be useful in alleviating radiation toxicity in patients. 


\section{NEW FINDINGS RELATED TO THE THESIS}

\section{Effects of the fullerene DF-1}

\subsection{Effects on overall survival}

We demonstrated radioprotection by the fullerene DF-1 in our in vivo zebrafish model.

DF-1 administered prior to irradiation afforded a significant survival advantage to zebrafish embryos exposed to either $20 \mathrm{~Gy}$ or $40 \mathrm{~Gy}$.

DF-1 was found to significantly enhance survival when given concurrently or up to 15 minutes after irradiation.

\subsection{Effects on organ-specific, radiation-induced damage}

DF-1 alleviated radiation-induced defects in the midline development of zebrafish embryos. It attenuated radiation-induced renal function defects.

\section{Effects of the proteasome inhibitor PS-341 (Bortezomib/VELCADE)}

PS-341 (1 $\mu \mathrm{mol} / \mathrm{L})$ markedly sensitized zebrafish embryos to the lethal effects of ionizing radiation when administered 1 hour prior to radiation.

\section{Effects of the NF-кBp65 inhibitor ethyl pyruvate}

We observed that EP not only protected against but also mitigated lethality associated with whole-body irradiation of zebrafish embryos. EP administered up to 2 hours after radiation significantly reduced ionizing radiation-associated lethality. EP was also found to be an effective ROS scavenger in irradiated zebrafish embryos.

\section{Effects of the IKK inhibitor CDDO-TFEA}

CDDO-TFEA protected against and mitigated overall lethal effects of radiation in zebrafish embryos in a manner similar to ethyl pyruvate. However, CDDO-TFEA, at least at the concentration $(1 \mu \mathrm{M})$ applied in our experimental model, did not demonstrate ROS scavenging properties.

\section{Organ-specific radiation protection by CDDO-TFEA and EP}


Both of them markedly reduced radiation-induced apoptosis as determined by acridine orange staining.

Treatment with EP but not CDDO-TFEA significantly reversed the effect of ionizing radiation on dextran clearance of irradiated zebrafish embryos to near normal levels, suggesting protection against ionizing radiation-induced kidney damage. Both reduced the incidence of curly-up phenotype. We assayed overall gastrointestinal function by evaluating long-term survival (up to 15 days) of zebrafish embryos irradiated in the presence and absence of either CDDO-TFEA or EP. Both compounds increased extended survival of zebrafish larvae. We also determined gastrointestinal lumen formation by use of the fluorescent reporter PED6. Pretreatment with EP or CDDO-TFEA restored, in part, the gastrointestinal lining of zebrafish embryos exposed to sublethal ionizing radiation exposure $(12 \mathrm{~Gy})$. 


\section{ÖSSZEFOGLALÁS}

Bevezetés: Az ionizáló sugárzás hatásait módosító anyagok az érdeklődés középpontjában állnak; jelentőségük meghatározó mind a kemo -és/vagy sugárterápia során, mind egy esetleges nukleáris baleset esetén. Egy közelmúltban végzett vizsgálatunkban glioblastomával diagnosztizált betegekben alkalmazott onkoterápián belül terápiás modalitások komplex alkalmazásait hasonlítottuk össze. A temozolomid alkilálószer sugárkezeléssel szimultán alkalmazása a tumorsejtek radioszenzitizálása révén növeli a kezelés hatékonyságát. Ugyanakkor létfontosságú az ép szövetek megkímélése az ionizáló sugárzással szemben; az ép szöveti sugártolerancia emelésének kiemelt szerepe van a terápiás index javítása céljából. Tanulmányunkban döntően in vivo kísérleteink során a zebradániót (Danio rerio), illetve annak embrióit, használtuk kísérleti modellünkhöz. E modell fő előnyei más állatmodellekhez viszonyítva a következők: nagy mintaszám, az embriók transzparenciája, és nagy hasonlóság az emberi genomhoz. A sugárhatást módosító anyagok közül klinikailag potenciálisan alkalmazhatók azon anyagok, mely szabad oxigéngyök fogó tulajdonságuk révén érik el a sugárvédelmet, illetve amelyek különböző molekuláris útvonalakon keresztül vezetnek sugárvédelemhez vagy sugárérzékenyítéshez. Általánosságban szignifikáns sugárvédelemre kis dózisú ionizáló sugárzás esetén számíthatunk, és a legtöbb sugárvédő anyag csak profilaktikusan alkalmazva képes radioprotektív hatást elérni.

Célkitűzés és kérdésfelvetés: Az ionizáló sugárzás hatásait módosító anyagok tesztelése volt a célunk. Az ionizáló sugárzás hatásainak módosítására különböző gyógyszercsoportba tartozó, más-más hatásmechanizmusú anyagokat teszteltünk.

Kísérleti zebradánió modellünkben azt vizsgáltuk, hogy a kutatásba bevont anyagok képesek-e a sugárzás káros hatásainak csökkentésére, a normál szöveti sugártolerancia javítására. Ha igen, akkor milyen mértékben és a sugárexpozíciót követöen mennyi ideig képesek arra? Arra is kerestük a választ, hogy a teljes túlélés javításán túl milyen szerv-specifikus védelem érhető el a sugárzás károsító hatásaival szemben.

Anyag és módszer: A kísérletes zebradánió modellben az ionizáló sugárzás hatásait vizsgáltuk ép, de fejlődésben lévő szövetekben teljestest-besugárzást követően. 
Anyagok: Elsőként egy fullerén szerkezetü nanopartikulum, a DF-1, lehetséges radioprotektív tulajdonságait értékeltük a túlélést, valamint a szerv-specifikus védelmet tekintve. Preklinikai kísérleteink során szuperoxid-dizmutáz mimetikumok két tagját is vizsgáltuk. E két csoport potens szabadgyök-fogóként is ismert. A tanulmány másik részében olyan szereket használtunk, amelyekröl ismert, hogy az NF-kappaB útvonalra is van hatásuk; ezek lehetséges sugárvédő vagy sugárérzékenyítő tulajdonságait teszteljük. Pozitív kontrollként - a humán felhasználásra már jóváhagyott sugárvédőt - az Amifostine-t használjuk.

Besugárzás: Életképes, egészséges zebradánió embriókat 20 Gy fotonnal végzett teljestestbesugárzásnak tettünk ki 24 órával a megtermékenyítést követően. A 20 Gy korábban LD50-ként volt definiálva, ezért választottuk ezt a dózist. A tesztelni kívánt anyagokat vagy a sugárexpozíció előtt vagy az után adtuk a halembriók médiumához.

Teljes túlélés és szerv-specifikus vizsgálatok: Az embriókat 7 napon keresztül követtük. Megfigyeltük a morfológiai elváltozásokat, valamint detektáltuk a teljes túlélést. Az apoptózis értékelésére akridin-narancs fluoreszcens assay-t használtunk. A gasztrointesztinális védelem megítéléséhez funkcionális és hosszú távú vizsgálatot alkalmaztunk, hisztológiai metszetekett készítettünk. A vesefunkciót egy a dextrán molekula exkrécióján alapuló vizsgálattal értékeltük. Bizonyos anyagok esetén NF-אB reporter assay-t és reverz transzkriptáz PCR-t is végeztünk, valamint használtunk antiszensz morfolinot is bizonyos kísérletekhez.

Eredmények: Mind 20, mind 40 Gy besugárzás esetén a DF-1 által nyújtott védelem hasonló volt az Amifostine általi radioprotekcióhoz. A legnagyobb túlélési előnyt, akkor figyeltük meg modellünkben, amikor a DF-1-et 3 órával a besugárzás előtt adagoltuk. Szintén vizsgáltuk, hogy a DF-1 tudja-e csökkenteni az ionizáló sugárzás káros hatásait, amikor a besugárzás után adagoltuk. Azt tapasztaltuk, hogy a DF-1 csak a sugárzást követő 15 percen belül adva volt képes javítani a túlélést. A DF-1 csökkentette a sugárzás indukálta gerincdefektust, javította a besugárzást követően észlelhető csökkent vesefunkciót. A reaktív oxigén származékok mérése azt mutatta, hogy a szabadgyökök szintje jelentősen lecsökkent a DF-1-gyel elökezelt embriókban, míg az irradiált kontrollban magas maradt.

Mindkét szuperoxid diszmutáz mimetikum szignifikánsan növelte a teljes túlélést a kontrollhoz képest. 


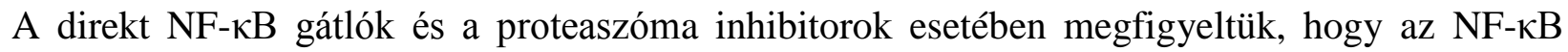
inhibitor etil-piruvát (EP) és CDDO-TFEA (szintetikus triterpenoid származék) védelmet biztosítottak az ionizáló sugárzás káros hatásai ellen, akkor is, ha a sugárexpozíció előtt vagy után (maximum 2 órával) adtuk ezen anyagok valamelyikét. Ez a sugárvédelem megmutatkozott több szerv tekintetében is, beleértve a gasztrointesztinális rendszert is. Ezzel szemben a proteaszóma inhibitor PS-341 (Velcade), melyet gyakran használnak az NF-kB aktivitás gátlására mind in vitro, mind a humángyógyászatban, nem protektált, hanem fokozta a sugárzással összefüggő toxicitást zebradánió modellünkben.

Diszkusszió: A DF-1-ről már ismert volt, hogy erős gyökfogó képességgel rendelkezik in vitro. Potens antioxidánskent sugárvédelmet nyújtott mind a teljes túlélés, mind pedig a szervspecifikus védelem tekintetében. A DF-1-gyel szerzett eredményeket összefoglalva, ezek a kísérletek is bizonyították, mint ahogy az várható volt egy antioxidánstól, hogy ez a módosított fullerén származék a sugárzást követően adagolva csak limitált ideig volt képes csökkenteni az ionizáló sugárzás káros hatásait.

A hat farmakológiai inhibitor (EP, CDDO-TFEA, és négy, kis molekulájú IKK gátló), mely a kanonikus NF-kB útvonalat gátolja, képes volt védelmet nyújtani az ionizáló sugárzás káros hatásai ellen. Ezzel szemben, az általunk vizsgált három proteaszóma inhibitor sugárvédelmet egyáltalán nem adott, hanem inkább érzékenyítette a zebradánió embriókat a sugárzással szemben.

A tumorsejtek NF-אB gátláson keresztüli sugárérzékenyítéséről nagyszámú tanulmány érhető el, míg az ionizáló sugárzásnak kitett normál szövetek és az NF-אB gátlás kapcsolatáról viszonylag kevesebb cikk áll rendelkezésre. A genetikailag módosított egér modellek alkalmazása limitált az

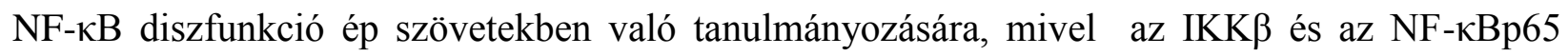
knockout állatok nem életképesek. Tanulmányunk megkerüli a fenti problémát, mert farmakológiai szereket használtunk olyan koncentrációban, amely az NF-кB aktivitást csökkenti, de nem gátolja teljesen. Ez a megközelítés lehetővé tette számunkra, hogy megfigyeljük ezen, különböző target specificitású és hatásmechanizmusú anyagok hatásait in vivo, valamint minimalizálta a farmakológiai szer ismeretlen, off-target hatása miatti zavaró tényezőket. Ahogy az várható volt, az antiszensz technikával az IKK $\beta$ és NF-kB p65 expresszió kiütésén keresztüli NF-kB gátlás embrionális letalitáshoz vezetett még genotoxikus stressz, esetünkben ionizáló 
sugárzásnak való kitettség, nélkül is. Ez az eredmény konzisztens azzal a nézettel, hogy a

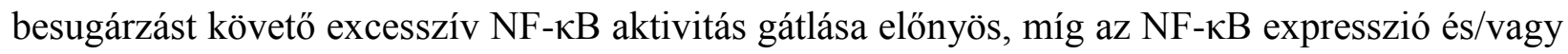
aktiváció teljes gátlása ártalmas, letális. Ennek megerősítését alátámasztja az a megfigyelésünk, hogy mind az EP, mind pedig a CDDO-TFEA nem toxikus koncentrációban csökkentette a TNF-

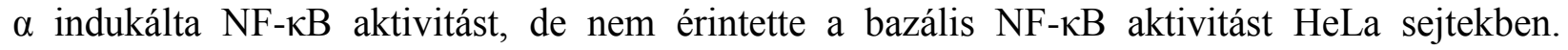
Kiemelendő, hogy az EP és a CDDO-TFEA nem csak a normál szöveti sugártoleranciát növelte, hanem a sugárexpozíciót követően 2 órán belül adva is javította a túlélést. Ez az eredmény inkább a gyulladásos válaszokra jellemző hosszantartó NF-kB aktiváció jelentőségére mutat rá, mint a közvetlenül a sugárexpozíció utáni hirtelen NF-кB aktivitás növekedésére.

Konklúzió: A tanulmány legfontosabb eredménye, hogy a direkt NF-kB gátlók hatékony sugárvédelmet nyújtottak mind a teljes túlélés, mind a szerv-specifikus védelem tekintetében az ionizáló sugárzás káros hatásai ellen. A direkt NF-кB inhibitorok antineoplasztikus hatást is kifejtenek, ahogyan azt más csoportok mutatták a szintetikus triterpenoid származékok esetében.

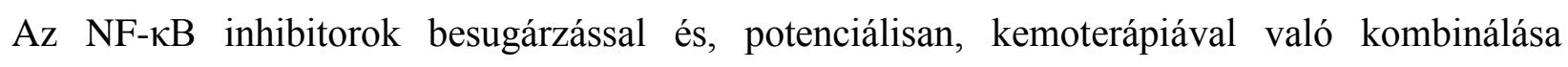
hozzájárulhat a terápiás index javításához. 


\section{ACKNOWLEDGMENTS}

I would like to express my sincere gratitude to my Ph.D. advisor, Dr. Katalin Hideghéty, for her guidance and support throughout this work, and last but not least, for her patience.

I thank Drs. Ulrich Rodeck and Adam Dicker for giving me the opportunity to work in their laboratories. 


\section{REFERENCES}

1. Trede NS, Langenau DM, Traver D, Look AT, Zon LI: The use of zebrafish to understand immunity. Immunity 2004, 20(4):367-379.

2. Zon LI, Peterson RT: In vivo drug discovery in the zebrafish. Nat Rev Drug Discov 2005, 4(1):35-44.

3. Sonis ST: The pathobiology of mucositis. Nat Rev Cancer 2004, 4(4):277-284.

4. Hall PD, Benko $H$, Hogan KR, Stuart RK: The influence of serum tumor necrosis factor-alpha and interleukin- 6 concentrations on nonhematologic toxicity and hematologic recovery in patients with acute myelogenous leukemia. Exp Hematol 1995, 23(12):1256-1260.

5. Stone HB, Moulder JE, Coleman CN, Ang KK, Anscher MS, Barcellos-Hoff MH, Dynan WS, Fike JR, Grdina DJ, Greenberger JS et al: Models for evaluating agents intended for the prophylaxis, mitigation and treatment of radiation injuries. Report of an NCl Workshop, December 3-4, 2003. Radiat Res 2004, 162(6):711-728.

6. Daroczi B, Szanto E, Toth J, Barzo P, Bognar L, Bako G, Mozes P, Szanto J, Hideghety K: Postoperative management of primary glioblastoma multiforme in patients over $\mathbf{6 0}$ years of age. Ideggyogyaszati Szemle/Clinical Neuroscience 2013, in press.

7. Richardson CF, Schuster DI, Wilson SR: Synthesis and characterization of water-soluble amino fullerene derivatives. Org Lett 2000, 2(8):1011-1014.

8. Brettreich M, Hirsch A: A highly water-soluble dendro[60]fullerene. Tetrahedron Lett 1998, 39: 2731-2734.

9. Ali SS, Hardt JI, Quick KL, Kim-Han JS, Erlanger BF, Huang TT, Epstein CJ, Dugan LL: A biologically effective fullerene (C60) derivative with superoxide dismutase mimetic properties. Free radical biology \& medicine 2004, 37(8):1191-1202.

10.Ghosh S, Hayden MS: New regulators of NF-kappaB in inflammation. Nat Rev Immunol 2008, 8(11):837-848.

11.Cusack JC, Jr., Liu R, Houston M, Abendroth K, Elliott PJ, Adams J, Baldwin AS, Jr.: Enhanced chemosensitivity to CPT-11 with proteasome inhibitor PS-341: implications for systemic nuclear factor-kappaB inhibition. Cancer Res 2001, 61(9):3535-3540.

12.Braunstein S, Formenti SC, Schneider RJ: Acquisition of stable inducible up-regulation of nuclear factor-kappaB by tumor necrosis factor exposure confers increased radiation resistance without increased transformation in breast cancer cells. Mol Cancer Res 2008, 6(1):78-88.

13.Ahmed KM, Li JJ: ATM-NF-kappaB connection as a target for tumor radiosensitization. Curr Cancer Drug Targets 2007, 7(4):335-342.

14.Kim BY, Kim KA, Kwon O, Kim SO, Kim MS, Kim BS, Oh WK, Kim GD, Jung M, Ahn JS: NF-kappaB inhibition radiosensitizes Ki-Ras-transformed cells to ionizing radiation. Carcinogenesis 2005, 26(8):1395-1403.

15.Munshi A, Kurland JF, Nishikawa T, Chiao PJ, Andreeff M, Meyn RE: Inhibition of constitutively activated nuclear factor-kappaB radiosensitizes human melanoma cells. Mol Cancer Ther 2004, 3(8):985-992.

16. Meyer CJ, Sporn MB, Wigley WC, Sonis ST: RTA 402 (CDDO-Me) suppresses tumor and treatment induced inflammation, sensitizing tumors to and protecting normal tissue from radiation. Eur $J$ Cancer 2006, 4:162.

17.Epperly M, Jin S, Nie S, Cao S, Zhang X, Franicola D, Wang H, Fink MP, Greenberger JS: Ethyl pyruvate, a potentially effective mitigator of damage after total-body irradiation. Radiat Res 2007, 168(5):552-559. 
18. Han Y, Englert JA, Yang R, Delude RL, Fink MP: Ethyl pyruvate inhibits nuclear factor-kappaBdependent signaling by directly targeting p65. J Pharmacol Exp Ther 2005, 312(3):1097-1105.

19.Shishodia S, Sethi G, Konopleva M, Andreeff M, Aggarwal BB: A synthetic triterpenoid, CDDO-Me, inhibits IkappaBalpha kinase and enhances apoptosis induced by TNF and chemotherapeutic agents through down-regulation of expression of nuclear factor kappaB-regulated gene products in human leukemic cells. Clin Cancer Res 2006, 12(6):1828-1838.

20.Liby K, Voong N, Williams CR, Risingsong R, Royce DB, Honda T, Gribble GW, Sporn MB, Letterio JJ: The synthetic triterpenoid CDDO-Imidazolide suppresses STAT phosphorylation and induces apoptosis in myeloma and lung cancer cells. Clin Cancer Res 2006, 12 (14 Pt 1):4288-4293.

21.Ahmad R, Raina D, Meyer C, Kufe D: Triterpenoid CDDO-methyl ester inhibits the Janus-activated kinase-1 (JAK1)-->signal transducer and activator of transcription-3 (STAT3) pathway by direct inhibition of JAK1 and STAT3. Cancer Res 2008, 68(8):2920-2926.

22.Perkins ND, Gilmore TD: Good cop, bad cop: the different faces of NF-kappaB. Cell Death Differ 2006, 13(5):759-772.

23.Zavrski I, Kleeberg L, Kaiser M, Fleissner C, Heider U, Sterz J, Jakob C, Sezer O: Proteasome as an emerging therapeutic target in cancer. Curr Pharm Des 2007, 13(5):471-485.

24.McAleer MF, Davidson C, Davidson WR, Yentzer B, Farber SA, Rodeck U, Dicker AP: Novel use of zebrafish as a vertebrate model to screen radiation protectors and sensitizers. International journal of radiation oncology, biology, physics 2005, 61(1):10-13.

25.Salvemini D, Mazzon E, Dugo L, Riley DP, Serraino I, Caputi AP, Cuzzocrea S: Pharmacological manipulation of the inflammatory cascade by the superoxide dismutase mimetic, M40403. $\mathrm{Br} J$ Pharmacol 2001, 132(4):815-827.

26.Batinic-Haberle I, Spasojevic I, Hambright P, Benov L, Cmmbliss AL, Fridovich I: Relationship among redox potentials, proton dissociation constants of pyrrolic nitrogens, and in vivo and in vitro superoxide dismutating activities of manganese(III) and iron(III) water-soluble porphyrins. Inorg Lett 1999, 38:4011-4022.

27. Hentschel DM, Park KM, Cilenti L, Zervos AS, Drummond I, Bonventre JV: Acute renal failure in zebrafish: a novel system to study a complex disease. Am J Physiol Renal Physiol 2005, 288(5):F923929.

28. Westerfield M: The zebrafish book. Eugene OR: University of Oregon Press; 1995

29.Farber SA, Pack M, Ho SY, Johnson ID, Wagner DS, Dosch R, Mullins MC, Hendrickson HS, Hendrickson EK, Halpern ME: Genetic analysis of digestive physiology using fluorescent phospholipid reporters. Science 2001, 292(5520):1385-1388.

30.Ren Q, Kari C, Quadros MR, Burd R, McCue P, Dicker AP, Rodeck U: Malignant transformation of immortalized HaCaT keratinocytes through deregulated nuclear factor kappaB signaling. Cancer Res 2006, 66(10):5209-5215.

31.Brand M, Heisenberg CP, Warga RM, Pelegri F, Karlstrom RO, Beuchle D, Picker A, Jiang YJ, FurutaniSeiki $M$, van Eeden FJ et al: Mutations affecting development of the midline and general body shape during zebrafish embryogenesis. Development 1996, 123:129-142.

32.Stone HB, Coleman CN, Anscher MS, McBride WH: Effects of radiation on normal tissue: consequences and mechanisms. Lancet Oncol 2003, 4(9):529-536.

33. Incardona JP, Collier TK, Scholz NL: Defects in cardiac function precede morphological abnormalities in fish embryos exposed to polycyclic aromatic hydrocarbons. Toxicol Appl Pharmacol 2004, 196(2):191-205.

34.Milano A, laffaioli RV, Caponigro F: The proteasome: a worthwhile target for the treatment of solid tumours? Eur J Cancer 2007, 43(7):1125-1133. 
35. Neukirchen J, Meier A, Rohrbeck A, Garcia-Pardillos G, Steidl U, Fenk R, Haas R, Kronenwett R, Rohr UP: The proteasome inhibitor bortezomib acts differently in combination with p53 gene transfer or cytotoxic chemotherapy on NSCLC cells. Cancer Gene Ther 2007, 14(4):431-439.

36.Russo SM, Tepper JE, Baldwin AS, Jr., Liu R, Adams J, Elliott P, Cusack JC, Jr.: Enhancement of radiosensitivity by proteasome inhibition: implications for a role of NF-kappaB. Int J Radiat Oncol Biol Phys 2001, 50(1):183-193.

37.Cardoso F, Durbecq V, Laes JF, Badran B, Lagneaux L, Bex F, Desmedt C, Willard-Gallo K, Ross JS, Burny A et al: Bortezomib (PS-341, Velcade) increases the efficacy of trastuzumab (Herceptin) in HER-2-positive breast cancer cells in a synergistic manner. Mol Cancer Ther 2006, 5(12):3042-3051.

38.McAleer MF, Duffy KT, Davidson WR, Kari G, Dicker AP, Rodeck U, Wickstrom E: Antisense inhibition of cyclin D1 expression is equivalent to flavopiridol for radiosensitization of zebrafish embryos. Int J Radiat Oncol Biol Phys 2006, 66(2):546-551.

39.Rock KL, Gramm C, Rothstein L, Clark K, Stein R, Dick L, Hwang D, Goldberg AL: Inhibitors of the proteasome block the degradation of most cell proteins and the generation of peptides presented on MHC class I molecules. Cell 1994, 78(5):761-771.

40.Komarov PG, Komarova EA, Kondratov RV, Christov-Tselkov K, Coon JS, Chernov MV, Gudkov AV: A chemical inhibitor of p53 that protects mice from the side effects of cancer therapy. Science 1999, 285(5434):1733-1737.

41.Komarova EA, Christov K, Faerman Al, Gudkov AV: Different impact of p53 and p21 on the radiation response of mouse tissues. Oncogene 2000, 19(33):3791-3798.

42.Komarova EA, Kondratov RV, Wang K, Christov K, Golovkina TV, Goldblum JR, Gudkov AV: Dual effect of $\mathrm{p} 53$ on radiation sensitivity in vivo: p53 promotes hematopoietic injury, but protects from gastro-intestinal syndrome in mice. Oncogene 2004, 23(19):3265-3271.

43.Berghmans S, Murphey RD, Wienholds E, Neuberg D, Kutok JL, Fletcher CD, Morris JP, Liu TX, SchulteMerker S, Kanki JP et al: tp53 mutant zebrafish develop malignant peripheral nerve sheath tumors. Proc Natl Acad Sci U S A 2005, 102(2):407-412.

44.Davidson W, Ren Q, Kari G, Kashi O, Dicker AP, Rodeck U: Inhibition of p73 function by Pifithrinalpha as revealed by studies in zebrafish embryos. Cell Cycle 2008, 7(9):1224-1230.

45.Langheinrich U, Hennen E, Stott G, Vacun G: Zebrafish as a model organism for the identification and characterization of drugs and genes affecting p53 signaling. Curr Biol 2002, 12(23):2023-2028.

46.Correa RG, Matsui T, Tergaonkar V, Rodriguez-Esteban C, Izpisua-Belmonte JC, Verma IM: Zebrafish IkappaB kinase 1 negatively regulates NF-kappaB activity. Curr Biol 2005, 15(14):1291-1295.

47.Correa RG, Tergaonkar V, Ng JK, Dubova I, Izpisua-Belmonte JC, Verma IM: Characterization of NFkappa B/I kappa B proteins in zebra fish and their involvement in notochord development. Mol Cell Biol 2004, 24(12):5257-5268.

48.Fink MP: Ethyl pyruvate: a novel anti-inflammatory agent. J Intern Med 2007, 261(4):349-362.

49.Daroczi B, Kari G, McAleer MF, Wolf JC, Rodeck U, Dicker AP: In vivo radioprotection by the fullerene nanoparticle DF-1 as assessed in a zebrafish model. Clinical cancer research : an official journal of the American Association for Cancer Research 2006, 12(23):7086-7091.

50.Yore MM, Liby KT, Honda T, Gribble GW, Sporn MB: The synthetic triterpenoid 1-[2-cyano-3,12dioxooleana-1,9(11)-dien-28-oyl]imidazole blocks nuclear factor-kappaB activation through direct inhibition of IkappaB kinase beta. Mol Cancer Ther 2006, 5(12):3232-3239.

51.Thimmulappa RK, Fuchs RJ, Malhotra D, Scollick C, Traore K, Bream JH, Trush MA, Liby KT, Sporn MB, Kensler TW et al: Preclinical evaluation of targeting the Nrf2 pathway by triterpenoids (CDDO-Im and CDDO-Me) for protection from LPS-induced inflammatory response and reactive oxygen species in human peripheral blood mononuclear cells and neutrophils. Antioxid Redox Signal 2007, 9(11):1963-1970. 
52.Yates MS, Tauchi M, Katsuoka F, Flanders KC, Liby KT, Honda T, Gribble GW, Johnson DA, Johnson JA, Burton NC et al: Pharmacodynamic characterization of chemopreventive triterpenoids as exceptionally potent inducers of Nrf2-regulated genes. Mol Cancer Ther 2007, 6(1):154-162.

53.Egan LJ, Eckmann L, Greten FR, Chae S, Li ZW, Myhre GM, Robine S, Karin M, Kagnoff MF: IkappaBkinasebeta-dependent NF-kappaB activation provides radioprotection to the intestinal epithelium. Proc Natl Acad Sci U S A 2004, 101(8):2452-2457.

54.Burdelya LG, Krivokrysenko VI, Tallant TC, Strom E, Gleiberman AS, Gupta D, Kurnasov OV, Fort FL, Osterman AL, Didonato JA et al: An agonist of toll-like receptor 5 has radioprotective activity in mouse and primate models. Science 2008, 320(5873):226-230.

55.Oberdorster E: Manufactured nanomaterials (fullerenes, $\mathrm{C60}$ ) induce oxidative stress in the brain of juvenile largemouth bass. Environ Health Perspect 2004, 112(10):1058-1062.

56.Thompson JS, Chu Y, Glass J, Tapp AA, Brown SA: The manganese superoxide dismutase mimetic, M40403, protects adult mice from lethal total body irradiation. Free Radic Res 2010, 44(5):529-540.

57. Makinde AY, Luo-Owen X, Rizvi A, Crapo JD, Pearlstein RD, Slater JM, Gridley DS: Effect of a metalloporphyrin antioxidant (MnTE-2-PyP) on the response of a mouse prostate cancer model to radiation. Anticancer Res 2009, 29(1):107-118.

58.Janssens S, Tschopp J: Signals from within: the DNA-damage-induced NF-kappaB response. Cell Death Differ 2006, 13(5):773-784.

59.Li Q, Van Antwerp D, Mercurio F, Lee KF, Verma IM: Severe liver degeneration in mice lacking the IkappaB kinase 2 gene. Science 1999, 284(5412):321-325.

60.Beg AA, Sha WC, Bronson RT, Ghosh S, Baltimore D: Embryonic lethality and liver degeneration in mice lacking the RelA component of NF-kappa B. Nature 1995, 376(6536):167-170.

61.Gerondakis S, Grumont R, Gugasyan R, Wong L, Isomura I, Ho W, Banerjee A: Unravelling the complexities of the NF-kappaB signalling pathway using mouse knockout and transgenic models. Oncogene 2006, 25(51):6781-6799.

62.Vijay-Kumar M, Gewirtz AT: Guardians of the gut: newly appreciated role of epithelial toll-like receptors in protecting the intestine. Gastroenterology 2008, 135(2):351-354.

63.Eckmann L, Nebelsiek T, Fingerle AA, Dann SM, Mages J, Lang R, Robine S, Kagnoff MF, Schmid RM, Karin $\mathrm{M}$ et al: Opposing functions of IKKbeta during acute and chronic intestinal inflammation. Proceedings of the National Academy of Sciences of the United States of America 2008, 105(39):15058-15063.

64.Groesdonk HV, Senftleben U: Modulation of inhibitor kappaB kinase/ nuclear factor kappaB signaling during critical illness: a double-edged sword. Critical care medicine 2004, 32(5):1239; author reply 1239-1240.

65.Sun Y, Gao X, Liu J, Kong QY, Wang XW, Chen XY, Wang Q, Cheng YF, Qu XX, Li H: Differential Notch1 and Notch2 expression and frequent activation of Notch signaling in gastric cancers. Archives of pathology \& laboratory medicine 2011, 135(4):451-458.

66.Kress CL, Konopleva M, Martinez-Garcia V, Krajewska M, Lefebvre S, Hyer ML, McQueen T, Andreeff $M$, Reed JC, Zapata JM: Triterpenoids display single agent anti-tumor activity in a transgenic mouse model of chronic lymphocytic leukemia and small B cell lymphoma. PloS one 2007, 2(6):e559.

67. Hyer ML, Croxton R, Krajewska M, Krajewski S, Kress CL, Lu M, Suh N, Sporn MB, Cryns VL, Zapata JM et al: Synthetic triterpenoids cooperate with tumor necrosis factor-related apoptosis-inducing ligand to induce apoptosis of breast cancer cells. Cancer research 2005, 65(11):4799-4808.

68.Chauhan D, Li G, Podar K, Hideshima T, Shringarpure R, Catley L, Mitsiades C, Munshi N, Tai YT, Suh N et al: The bortezomib/proteasome inhibitor PS-341 and triterpenoid CDDO-Im induce synergistic anti-multiple myeloma (MM) activity and overcome bortezomib resistance. Blood 2004, 103(8):3158-3166. 
69.Place AE, Suh N, Williams CR, Risingsong R, Honda T, Honda Y, Gribble GW, Leesnitzer LM, Stimmel $\mathrm{JB}$, Willson TM et al: The novel synthetic triterpenoid, CDDO-imidazolide, inhibits inflammatory response and tumor growth in vivo. Clinical cancer research : an official journal of the American Association for Cancer Research 2003, 9(7):2798-2806.

70.Ito $\mathrm{Y}$, Pandey $\mathrm{P}$, Sporn MB, Datta R, Kharbanda S, Kufe D: The novel triterpenoid CDDO induces apoptosis and differentiation of human osteosarcoma cells by a caspase-8 dependent mechanism. Molecular pharmacology 2001, 59(5):1094-1099.

71.Ito Y, Pandey P, Place A, Sporn MB, Gribble GW, Honda T, Kharbanda S, Kufe D: The novel triterpenoid 2-cyano-3,12-dioxoolean-1,9-dien-28-oic acid induces apoptosis of human myeloid leukemia cells by a caspase-8-dependent mechanism. Cell growth \& differentiation : the molecular biology journal of the American Association for Cancer Research 2000, 11(5):261-267. 